\title{
Nutraceautical wild Fruits of India-Lasora (Cordia)-History, Origin and Folklore
}

\author{
Ahuja, S. C ${ }^{1 *}$, Siddharth Ahuja ${ }^{2}$, Uma Ahuja ${ }^{3}$
}

${ }^{1}$ Retired Plant Pathologist, Rice Research Station, V \& PO Kaul, District Kaithal, 136021, India

${ }^{2}$ Assistant Professor, Department of Pharmacology, Sahid Hasan Khan Mewati Medical College Nalharh, Mewat, Haryana, India

${ }^{3}$ Retired Professor, Genetics and Plant Breeding, College of Agriculture, CCS Haryana Agricultural University, V\&PO Kaul, District Kaithal, Haryana-136021, India

*Corresponding author: Ahuja, S. C

Abstract

Strikingly similar fruits of Cordia dichotoma, C. myxa and C. sinensis are known as Lasora in vernacular languages in India and Pakistan. The trio has been used since ages in India, Indonesia, Iran, Iraq, Arab and Africa as folk medicine and in Ayurvedic, Arabian, Chinese, Unani (Greek), Persian and Siddha systems of medicine. Most of plant parts, like roots, twigs, roots, stem and root bark, leaves, seeds and even the gum are useful. Folks in various countries and parts of India use fruits, tender leaves and inflorescence as vegetable. Fruits are eaten as raw and used pickled. In many parts of India, Africa and East Asia these species serve as source of survival and food during famines. Cordia has long been used as an anti-diabetic, anthelminth, anti-inflammatory, anti-malarial, astringent, cicatrizant, diuretic, hepato-protective, immune-modulator and febrifuge and as an appetite and cough suppressant in folkloric and traditional medicine. Cordia for long employed to treat urinary infections, lung diseases and leprosy in traditional medicine. The timber and wood is turned into various types of handles, utensils and agricultural tools. Trio seems to be a future green resource source of dye, fodder, fiber, as a corrosion inhibitor, cosmetic and anti-aging agent, pharmaceutical binder for tablets, sustained drug delivery and an anti-capping agent. The present paper reviews the history, distribution, use as food, forage and feed, as medicine in folk, animal and human health; pharmaceutical and therapeutic uses, cultural, ecological and nutritional value, and miscellaneous uses and disadvantages of Lasora.

Keywords: Cordia dichotoma, Lasora, folk medicine, Ayurvedic.

Copyright @ 2020: This is an open-access article distributed under the terms of the Creative Commons Attribution license which permits unrestricted use, distribution, and reproduction in any medium for non-commercial use (NonCommercial, or CC-BY-NC) provided the original author and source are credited

\section{INTRODUCTION}

In India and Pakistan, the plants and fruits of Cordia dichotoma, C. myxa, and C. sinensis are known as Lasora. Genus owes its name to the German Physician and Botanists, Euricius Cordus (1486-1535) and his son Valerius Cordus (1515-1544), after whom Linnaeus named the taxon in 1753. Species names dichotoma and myxa are derived from Greek words, dichotomous (meaning cut in two equal halves) and myxa (mucus) respectively while sinensis is from Latin word for Chinese. C. myxa L. described by Linnaeus is divided today into three species: Cordia myxa L., C. crenata Del., and C. dichotoma Forst. (= C. obliqua Wild.) [1].

\section{Habit and Distribution}

Cordias are small to medium sized trees up to 5-10 $\mathrm{m}$ height with a short bole and spreading crown. These grow wild, rarely cultivated and are found growing singly. The stem bark is grayish brown, smooth or longitudinally wrinkled. Flowers are white, fragrant in large lax terminal and axillary, peduncle cymes which open only at night. Flowering time varies from place to place. Flowering starts from Feb- May according to regions. Trees bear cherry-sized fruit from March through June in some parts of India, and July through August in other regions [2]. Sanskrit entitled Namarupajnanam [3] describes Cordia dichotoma (Sleshmastaka)as a handsome middle-sized tree (kantavrksaka) growing wildly in hilly area (sailusa, sailu) with fragrant flowers (gandhapuspa) appearing in spring (vasantakusuma) having pearl shaped fruits (muktaphala) in abundance (bahuphala), with slimy and sticky pulp (picchila) which are cold to touch as well as in virya (sitaphala). It is disliked by noble persons and birds (dvijakutsita). The pulp is sweet with slightly astringent drying after-taste.

\section{The Three Cordias}

C. dichotoma Forst. f. (CD) known popularly as Indian cherry is native to northern India, Pakistan, Nepal, Sri Lanka, Myanmar, The Philippines, China, 
Ryuku Islands, Taiwan, New Guinea, northern Australia and New Caledonia. In India, CD grows in wild form in the states of Rajasthan, Punjab, Haryana, Himachal Pradesh, Uttar Pradesh, Madhya Pradesh, Maharashtra, Gujarat, Bihar, Andaman, Nicobar and Diu islands. It was introduced in Mauritius around 1837 and is naturalized in the coastal zone and along roads [4] $C D$ has been named variously as $C$. oblique Willd., $C$. obliqua Willd., C. myxa auct. Non L. (but not of L.), $C$. griffithii C. B. Clarke., C. ixiocarpa F. Muell., $C$. brownie DC. and C. wallichii G. Don. [5]

C. myxa L.(CM) known as Assyrian plum is found both in the temperate and tropic regions of world and is a native of India, Iran and Pakistan and naturalized in southern Iran and Iraq, various oases in Arabia, some Mediterranean districts and in northern and tropical Africa [6]. Plant also occurs in Myanmar, Sri Lanka, China, and tropical Australia [7]. For synonymy see Cordia myxa L.-The plant list [8]

C. sinensis Lam.(CS) is native to Egypt, Ethiopia, India, Israel, Jordan, Madagascar, Mozambique, Namibia, Pakistan, Senegal, Somalia, South Africa, Sri Lanka, Kenya, Sudan, Tanzania, Yemen and Zimbabwe [9]. In India, it grows in Delhi, Haryana, Punjab, Rajasthan, Gujarat and South India, called Gondhi or Gondhini, laghuslemastaka. In Ayurveda, plant is considered as a source of Laghuslemastaka, a substitute of Slemastaka [10]. CS has been named variously as Cordia gharaf (Forssk.) Ehrenb. ex Asch.; Cordia reticulata Roth ) non Vahl; Cordia rothii Roem. \& Schult.; Cordia subopposita DC. and Cordia oblongifolia Hochst. ex DC. [11]

$\mathrm{CD}$ and $\mathrm{CM}$ produce big while $\mathrm{CS}$ yields smaller fruits and is referred as small lasora or Laghuslemastaka. Plants of $\mathrm{CM}$ and $\mathrm{CD}$ are similar therefore confused and difficult to differentiate the two but the fruit of former tends to be more tan than pink. Wild relatives of $C$. myxa $(=C D)$ and $C$. sinensis $(=C$. rothii) occur in Gangetic plains of India [12].

\section{HISTORY}

\section{Written Records}

Lasora fruit finds reference in ancient Indian scriptures as Manusmriti (2000BC), Kalpasutra (1500-800BC), Valmiki's Ramayana (500AD), Mahabharata (in present form, $400 \mathrm{AD}$ ), Brhatsamhita of Varahmihira (505-587 AD), Amarkosha (500-800 AD), Vishvavallabha of Chakrapani (1577 AD) [13-15] and in Manasollasa (12 ${ }^{\text {th }}$ Century) [16]. Among ancient and, it is referred and described Ayurvedic treatises as Charak Samhita (600BC), various other Nighantus, and agricultural treatise, Vrikshayurveda of Surpala (1000 AD) [17].

The history of CM and CS may be traced from history of bird liming. The first-century geographer
Strabo mentions about birdlime being used to catch apes in India during the period of Alexander's attack [18]. CS is recorded in Egypt since the pre-dynastic period (3100 BC) [19]. Probably the earliest reference to $C$. myxa (slemastaki) in India appears to be in Kautilya's Arthashashtra (321-296BCE) [20]. The earliest written record of $\mathrm{CM}$ in Africa seems to be is that of Theophrastus (Enquiry into Plants 4.2.10; 372-287BC) where he mentioned cake making from fruits of $\mathrm{CM}$ in Thebes, Egypt. According to Pliny, CM acclimatized in Italy, in the early Roman period. It finds reference in Hebrew texts of the Roman period (Mishnah, Shabbat 8.4; 2nd cent. AD; Babylonian Talmud (Jewish six) (Abodah Zarah 14a; Bekhoroth 8a\}. Mattiolus, Italian Physician, Botanist (1500-1577) mentioned export of $\mathrm{CM}$ glue from Syria (including Palestine) and Egypt to Venice [6, 21] Kislev [6] writes "Pharchi (1852), who lived in Palestine in the fourteenth century A.D., translated gufnin (in Mishnah, Demai; Babylonian Talmud, Berakoth 40.2) as sebesten". At Carthage, the eastern Roman Empire, Cordia has been noticed during the Byzantine period [22].

\section{Archaeological Evidences}

Fossils found in several layers at Inamgaon in India as 11 stones were identified as CM [23]; Kislev [6] has treated these as $\mathrm{CD}$ on basis of the prevailing confusion in nomenclature. The earliest fossil record of C. myxa L. in modern Israel and Egypt seems to be that found at Ashkelon dating back to the medieval Islamic period (10 to $12^{\text {th }}$ Century AD) $[6,21]$.

\section{Names}

CD is referred as Selu in Manusmrti (2000 BC) and Uddalak in Valmiki Ramayana [13]. Amarkosha (500-800 AD) lists five names in Sanskrit (Selu, Slesmatak, Sheet, Udalo and Bahuvara) while Namarupajnanam as mentioned earlier, provides 11 names of CD based on the plant character [3].

Vernacular and common names of three Cordia species are prevalent in as many as 67 languages, dialects / countries (Table-1). CD and CS respectively have higher number of names and in more Asian and African languages/ dialects indicating their nativity and distribution. The common Hindi name for CD, is spelled variously as Lasora, Lahsaura, Lasoora, Lasura, Lasuda, Lasoda, Lashora and Lisora. CD has more names in Kannada and Tamil (22 each), Telugu [18] and Marathi [17] followed by Hindi and Sanskrit (Table-1).

\section{Uses}

Fruits, twigs, leaves, stem bark, gum and roots of the trio offer multifarious uses. In Ethiopia, Kenya, Tanzania, Uganda and Zimbabwe, CS is a tree of many uses in Africa as; fruits and seed are edible, parts used as human and veterinary medicine, vermifuge, fodder, and bird forage. Wood is used as firewood, timber, and for making charcoal and furniture, tools, carvings, utensils, 
walking sticks and arrow. Its resin, gum and latex are also useful. In addition these items of day to day use, it plays important role in rituals [24].

\section{Food}

The kernel, leaves, flowers, tender branches of $\mathrm{CD}, \mathrm{CM}$ and $\mathrm{CS}$ are edible and used as a food. Ripe fruits of the three species are edible and eaten fresh, while unripe fruits are used as vegetable and pickled [25, 26]. Leaves, flower buds and fruits are used as vegetable.

\section{Fruits}

When fresh, fruit is slightly astringent but pleasant-tasting and thirst-quenching. Tribals in Poona, coastal areas of Orissa, Miris of Assam and Palliyars of Tamil Nadu eat the ripe CD fruits raw [27-29]. The Malinke ethnic of Senegal eat wild CM fruits [30] and Maasai, Sanjoo, Gogos, Kurya, Barbaigs and Zulu tribes of Kenya and tribes in Akole, Tehsil, Ahmednagar, India consume CS fruits $[31,32]$. CS fruit serves as a famine food for the Kara and Kwega tribe of Ethiopia [33].

Earlier, CM fruits and Pterocarpus santaloides were used to sweeten porridge. Now, its use is supplanted by industrial sugar despite the risks [30]. While in Tanzania, CS fruit is used in porridge as a sugar substitute besides consumption as a dessert with baobab meal [24]. The sweet mucilaginous pulp may be eaten fresh while fruit cover and seeds are discarded. Large quantities of the CS fruits are gathered, pounded to a sticky mass, sun-dried and stored in a wooden container (Turkana). Whenever it is needed, water is added to soften it before being served.

\section{As a Vegetable}

Mahers in Gujarat, people of Rajasthan and HP in India and Rendille in Kenya use unripe fruits as vegetable [34, 35]. Folks in Rajasthan cook fruits of gunda (CM), gundi (Cordia gharaf = CS) and saijna (Moringa oleifera) together and eat as a vegetable. The famous pachkutta (fruit of five trees) includes kair (Capparis decidua), kumut (Acacia Senegal), sangri (Prosopis cineraria), kachra (Cucumis spp.) and gunda (CM). All these five are mixed together and cooked as a nutritious vegetable eaten along with bread [36]. People in Maharashtra prepare the young inflorescence into a vegetable while those in Alaknanda Valley, Garhwal; Himachal Pradesh, Chhattisgarh, and Gujarat, tribes in Ahmednagar and Kolhapur Districts of Maharashtra, Bastar and Mandala district of Madhya Pradesh and Pa-O (Karen) of Myanmar use leaves as vegetable [37-41]. Santals and others in MP eat tender leaves alone while in Mizoram, folks eat leaves with meat [42]. Manabos of Philippines eat young leaves dipped in honey in times of famine. CS serves as a good source of food for the wandering pastoralists in East Africa. Humans and animals use leaves, flowers, fruit and kernel as food while Pokot and Maasai tribes eat the raw root
[43, 44]. For the Rendille people of Kenya fruits are virtually the only fresh vegetable foodstuff.

The seed can also be eaten as a nut. The stone of $\mathrm{CD}$ has a heavy, disagreeable odor when cut, but its kernel tastes like fresh filberts [45]. A clear gum produced is also edible.

\section{As Spice}

$\mathrm{CD}$ and $\mathrm{CM}$ fruits are used as spices in many countries. Dried CM fruits are sold in the spice markets of Egypt as sapistan [46]. CD fruit has a tart, tangy flavor and used in sautéing and marinating and to stupefy. Its flavor complements a number of spices as Ker (Capparis decidua), raw mango, raw papaya, lemon, garlic, ginger, vinegar, chili, turmeric and cumin. In Taiwan fruits are pickled whole and used in soups and as a topping for tofu and vegetables. In Indonesia, CD leaves are used to wrap fish for cooking. Green, unripe fruit has a sour taste that can easily be confused for raw mango in its pickled form. In India, sour unripe fruits are cut in half, destoned and pickled while in Taiwan it is pickled along with seeds and is used as an appetizer. Sandawe tribe in Kenya uses CS roots for flavouring [43].

\section{Use in Brewing}

People in various places use the trio in brewing liquor and for flavoring. People in East Africa, use the CS fruit pulp for brewing local beer. Folks in Uttar Pradesh, India, use ripened CD fruits in making country liquor and while in Tropical Africa and Himachal Pradesh, India folk use CM fruits to flavor sorghum beer and food $[45,47,48]$. The fresh CS fruits are squeezed in water to dissolve the pulp and made into juice. The juice is mixed with tamarind (Tamarindus indica) juice and fermented. Fresh juice may also be drunk (Turkana). In Nebi district, Uganda fruit juice is fermented to make alcoholic beverage [49]. In Taiwan Cumming cordia (CD) is converted by boiling into Pobzuihi, a widely used traditional food [50]. The fermented fruits together with black beans are used in Chinese cooking and fresh fruits to stupefy fish.

\section{Fodder and forage}

CM leaves serve as a good fodder and lopped for this purpose. The fruit are an important food for antelopes, giraffe, deer, monkeys, baboons, Asian elephants and birds. The leaves provide browse for animals such as antelope, giraffe and deer and serve as fodder for goats and as feed for larvae of the butterfly and serve good forage for elephants and honey bees. In Berenty, Madgascar, the lemurs feed leaf and floral buds. The camels have a very strong liking for CS. In Pureto Rico leaves serve as a feed for Zenaida Dove (Zenaida aurita). In Iran CM fruits are used in feed of animals as antimicrobial particularly for gastrointestinal disorders and analgesia [51]. 
CD leaves contain 12-15\% crude protein, $16-27 \%$ crude fibre, $42-53 \%$ nitrogen-free extract, $2-3$ $\%$ ether extract, $13-17 \%$ total ash, 2-4 \% calcium and about $0.3 \%$ phosphorus [9.1]. Nutritive value of fodder is DCP (Digestible Crude Protein) $5.4 \mathrm{~kg}$, TDN (Total Digestible Nitrogen) 26.9 [52]. The DCP is fairly high as compared to conventional fodders. The TDN is lower in compared to poor type roughages. CD seed kernel contains a high proportion of fatty oils and proteins (46 and $31 \%$, respectively) which has potential as cattle feed. The fruit pulp and seeds contain $(51.8 \%)$ oil [53].

Leaves of CD, Moringa oleifera, Albizia lebbeck, guava and fruits of $\mathrm{CD}$ as well as clove show fed in fodder show anti-methanogenic activity [54]. Supplementation of CD leaves @ 5\% in OM with wheat straw, afforded increased body weight gain (17\%) in lactating buffaloes without any change in milk yield and composition [55].

\section{Medicine}

C. dichotoma, C. myxa and C. sinensis have been used in medicine for human and animals since long.

\section{Veterinary}

Three Cordias are widely used in treatment of animal ailments in Africa and India. They are traditionally used to check bloat and diarrhea, fix fractured bones, aid in conceiving, prevent uterus -prolapse and yoke gall [56].

In Gujarat CS (=C. gharaf) fruits, leaves and branches are fed to animals for treatment of diarrhea [57]. Ash of Pearl millet and CD leaves is used to cure uterus prolapse [58]. Drenching with daadriya herb blended CM gum in groundnut oil cures foot and mouth disease of cattle [59]. Drenching the animal with CM bark paste and Flacourtia indica mixed in water is given for easy calving [60]

Tender leaves of Cordia along with small bulbs of Allium cepa are fed to the cows and buffaloes prior to heat period to increase fertility and chances of conception. Similarly, an extract of Cordia, sugar and majith (Rubia cordifolia L. sensu Hook f.) is also used to aid cows and buffaloes to conceive [61]. CD leaf ash is used to prevent yoke gall [62]. In Gujarat, CD bark paste is used for fractures [63]. Strips of dry inner bark of CS (=CG, CR) are tied on fractured bone of cattle leg [35]. Fresh and semi-ripen $\mathrm{CD}$ fruit juice mixed with sugar is used to cure pneumonia in goats and sheep [64].

Maasai of Tanzania use stem bark, roots, roots without bark, root decoction and bark in treating cattle diseases [65]. While in Ormaland - Kenya, use of CS twig checks mastitis [66]. Zarmas of southwestern Niger, West Africa use CS root and stem bark decoction for washing inflamed eyes of animals [67] and tribes in Tanzania use these for bovine conjunctivitis [24, 68, 69].
In Sudan, stem bark of Cordia ovalis and CS is used in itchy skin and to retain placenta [70].

\section{Traditional Medicine Systems}

In addition to folk uses plants and parts are widely used in Unani (Greek), Chinese, Ayurvedic and Siddha system of medicine.

\section{Unani (Greek) System}

In Unani system the plant is used as antibacterial, antiviral and antitussive (anti cough). CD is chief ingredient of Joshandah, polyherbal formulations, extensively used by the masses in India for the treatment of common cold, catarrh, cough, respiratory distress, and fevers. CD is also used in Pakistan in Unani (Greek) preparation of formulations as Arq Hara Bhara, Dayaquza, Itrifal Zamani, Joshanda, Laooq Sapistan, Laooq Sapistan Khiyar Shanbari, Safuf Habis, Sherbet Arzani, Sherbet Shafa, and Shrebet Zufah Murakkab compounds. In Unani medicine, the fruit supplemented purgatives as a way of counteracting their bad side effects [2].

\section{Chinese Pharmacopia}

In Uighur medicine, healers use Abnormal Savda Munziq (ASMq), an herbal formula composed of 10 medicinal herbs including $\mathrm{CD}$ as an important component [71] for preventing cancer, diabetes, cardiovascular disorders, and chronic asthma [72].

\section{In Ayurveda}

A number Cordia species find mention in Ayurveda literature and Materia Medicas for the treatment of various disease and disorder conditions. CD finds reference in a many Ayurvedic treatises: Kaidav nighantu, Nighantu adarsh, Shankar nighantu, Bhavprakash nighantu, Raaj nighantu, and Madanpal nighantu [17]. Almost all plant parts of CD are used for medicinal purposes. Names of CD in Sanskrit indicate that plant is efficacious in many disorders (uddala, bahuvara) and is anti-poisonous (visaghati) [3].

The unripe and ripe fruits, leaves, bark and seed oil possesses specific Ayurvedic characteristics that determine their respective use. Sason and Sharma [17] presents a comparative table of the Guna (quality), Karma (action) and indications for various ailments cured with CD as described in various Nigantus. Plant is used in dyspepsia, fever, diarrhea, leprosy, skin diseases, dry cough, jaundice, wound purification, mouth ulcer, gonorrhea, ringworm and to increase male potency. Being sweet, astringent and bitter in taste, $\mathrm{CD}$ acts as hair tonic and controls poison, skin eruptions, ulcers, and herpetic skin lesions, other type of skin diseases and vitiated humors $\{$ kappha(phlegm) and pitta(bile) $\}$.

The ripe CD fruit is sweet in taste and being demulcent enhances kappha and cold. Fruit is considered cold to touch as well as virya (potency) and therefore, 
called as (sitaphala, cold fruit). As a drug, it excites kappha (slesmataka) and induces sleep (selu). The fruits are used against diarrhoea, cold, acidity and delirium [73, 74]. CD fruit acts as an expectorant, diuretic and anthelmintic. Sushutra, prescribes Cordia fruits as a coolant and astringent, to be used for biliousness, cough and internal hemorrhage.

Its unripe fruit is constipative, drying, and controls the vitiation of Pitta, Kappha, and Rakta (blood), balances Kappha in the body. It is used in the treatment of fever of various etiology, cough, bronchitis, asthma, rhinitis and balances in the body. The half ripe fruit makes a tasty broth which is hot in effect as per Ayurveda practitioners. The fruit makes an excellent pickle too which is not so hot. In fact the preserve is quite effective against indigestion. A fine powder of tender fruits mixed with goat milk and sugar destroys upadamsa (soft chancre) [75].

Carak-samhita(C-S) and Sushrut-samhita (SS) describe use of bark paste in eruptive boils (Vrindamadhava, VM ), in case of poison entered into blood, in all type of spider poisoning, to control intrinsic hemorrhage and in erysipelas. Bark paste is applied to eyes (C-S) and oil from seed kernels is used as snuff and massage for blackening of hair (Cakradatta) [76]. Kauyliya Arthshastra refers to use of Cordia as a constituent of the remedy against poisons and poisonous compounds applied against one's own enemy or people [21].

It is one of the constituent in formulation: Lauk Aspistan, used for cough and cold, makes phlegm thin and extrudes it. Ripe and dry fruit is a constituent of syrup Jhuffa used as anupan (adjutant) for taking Bhagotar Gutika prescribed to check cough and asthama [79]. Karbudar (lasoda) is a constituent of many formulations used to do emesis (of upper part of body [75]. It is one among the constituents of Gojihvaadi kvaatha /choorna and Putikranjadhayadi choorna [77].

\section{As Folk Medicine}

The trio has been used in folk medicine since long. Folk use of CD is common in India, Indonesia, the Philippines, Thailand and Indo-China, that of CS in India, Djibouti, Kenya, Ethiopia, Somalia, South Africa and $C$. myxa in Europe, Africa, Iran, Baluchistan, Pakistan, and India.

$\mathrm{CD}$ is serves as immunomodulator, antidiabetic, anthelmintic, astringent, diuretic, hepato-protective, demulcent and expectorant [78, 79]. In folk medicine it is used in treatment of inflammation, bronchitis, fever, wound healing, chest infection, lung disease, cholera, cold, colic, constipation, cough, headache, ulcers, urine disease and urticaria. In UP, CD plant is used in chronic orthopedic fever, dropsy, dysentery, dyspepsia, cholera, catarrh, and headache and skin diseases [80].

Some ethnic communities use leaf decoction and leaf extract to cure cough, sore throat and in hair oil [81-84]. In Rajasthan, the leaf juice is considered cooling, and is applied as a poultice to treat migraine, inflammation and swellings. Green fresh leaves are used in treatment of jaundice and for increasing power in Pakistan and Andhra Pradesh [85, 86]. In Sindh Pakistan, people use leaves for hepatitis and asthma [80]. Gond Maria and Halba tribals of Madhya Pradesh use leaf paste for ulcers [88]. In Mali, Cote de ivore and UP India, people apply the leaves to wounds, ulcers and headache [84] and to treat the effects of tse-tse fly and other insect bites [81, 89].

Bark decoction aids in digestion and clears up digestive problems. Stem bark decoction is taken for dyspepsia, fever, diarrhea, dysentery, headache, stomach-ache, indigestion, burning sensation, leprosy, skin diseases and as a tonic in various parts of India [90-92]. In Myanmar bark is used to treat catarrh and the Javanese use it for fevers [89]. Tribals in Puna use bark and fruits in respiratory tract infections, cough and as an anthelminthic [40]. In Orissa stem bark-is used as an astringent and in toothache and for strengthening teeth [93]. The bark juice administered in coconut milk is given in severe colicky pains [94]. The powdered bark is put on mouth ulcers and its infusion is used as a gargle for sore throats. Moistened bark is applied externally on boils and tumors to hasten ripening. The Santals use bark powder for external application in prurigo. Tribals of Nizamabad, Andhra Pradesh, orally take stem bark extract for cure of scabies [95]. Lodhas use stem bark decoction with common salt $(3: 1)$ in gripe [82].

Lodhas prescribe root bark paste as cure for eruptions like pimples [82]. Folk in Sri Lanka use CD in bronchial diseases and pneumonia, bark as a laxative and root in urinary diseases [96].

Tribals in North Gujarat take mixture of CD flowers and curd to protect body against heavy sun heat waves [97].

CD fruit is very mucilaginous and highly esteemed for coughs and diseases of the chest, uterus and urethra. Consumption of ripe sweet fruits reduces the inflammation due to acidity [98].The fruits are useful in ulcers, leprosy, skin diseases, burning sensation, bronchitis, dry cough, constipation and chronic fever $[88,91]$. Santhals use ripe fruits as purgative and Lodhas give fruit mucilage with paste of long peppers $(2: 1)$ as demulcent [82].

In HP fruit is given as expectorant in curing lung diseases [99]. Similarly, people of Rajasthan, use a decoction of fennel, CD and munaka (dried large raisin) 
to soften and draw the cough out of body [100] while in Aligarh, folk take pills of crushed, roasted fruits of CD, Psidium guajava, Solanum surtense, Syzygium cumini and Calotopis procera, mixed with honey to cure cough and asthma [101].

In North Karnataka oral intake of fruit juice used as a blood purifier [102]. In Pakistan CD fruit is considered demulcent, expectorant, tonic and refrigerant and used to reduce irritation of urinary passage, alleviation of thirst and dry cough [103].

Lodhas of MP, India use CD dried seed powder with seed oil of Schleichera oloesa for removing tattooing marks on forehead. Powdered seed mixed with oil applied topically is a good remedy of ring worm [82, 91]. Seed decoction is used for sore throat [81]

\section{Folk Medicine}

Sebesten plums (CM) have analgesic, astringent, anti-inflammatory, emollient, lubricating, softening and laxative properties. Written sources show that Sebasten fruits were used in Rome more as medicine than as food. CM is widely used as traditional medicine for coughs, chest-complaints, inflammations of the digestive and urinary tract in tropical Africa, in the near and Middle East and were also used in Western Europe, towards the 18th and beginning of the 19th centuries [104]. Santhals use CM in fever, dropsy, anasarca, urticaria and dyspepsia, cholera and dysentery [105].

In Africa, the fruit pulp is employed to treat diarrhea, dysentery, tuberculosis, wounds, ulcers, calm abscesses and rheumatic pains and as a vermifuge [45, 89]. In Tanzania the fruit pulp is applied to ring worm. In Malaysia, the fruit mucilage is given to treat coughs and other chest complaints. It is also used to treat uterus and urethra disorders [94].

Unripe fruit used in pickle is carminative and ripened fruit is used in the medicines for lungs and pulp in medicines for brain [86]. In Iran, CM with three other seeds (Barhang, Plantago major L., Gudamah, Alyssum campestre L. and bihidana, Pyrus cydonia L.) is used as a tonic and remedy for diarrhea. Being demulcent it is useful for coughs and chest complaints. A mixture of Cordia myxa and other fruits with lime juice and sugar, is given as an infusion for headache, fevers (not malarial), and to soften faces before purgation [106]. In Iran, traditional healers (Attar) use CM fruit for pharyngitis and as antitussive (cough), febrifuge and laxative [107]. In India the fruits are used in constipation, stomach worms, piles and toothache [108].

CM root mixed with Viola sp., Nymphaea alba L., and Cichorium intybus L. is used in Iran, Baluchistan, and India as a resolvent and cooling medicine for bilious attacks [106]. Tribes in Africa use root decoction to treat malaria in Africa but it can cause an abortion [69]. In
Sindh, Pakistan, people use the whole plant of liyar $(\mathrm{CM})$ in hepatitis and against post injury infection and leaves in treatment of jaundice.

In India folk apply stem bark paste over skin for herpes Zoster and over spider bite portion of skin [109] and folks in Orissa use stem bark as astringent and in toothache [110]. Bark decoction being astringent and used as gargle. Mixed with catechu stem bark is chewed as a substitute for pan (betel leaves) to redden lips [108].

\section{CS in Folk Medicine}

CS is used traditionally for headaches, cough, chest complaints, fever, malaria, intestinal disorders, conjunctivitis, rheumatism, edema, gonorrhea, syphilis, rabies, sickle cell anemia, ulcer, toothache, worm infestation and as diuretics $[31,68]$.

Both CS roots and bark are used to treat a variety of disorders in humans and livestock. The Samburu of Kenya use CS bark for diarrhea and chest pains $[111,112]$ or pleurisy associated with lung infection. Borana people in Ethiopia, chew bark for stomach disorders. In India, bark is used as astringent in Orissa. 2-3 gm of powders of Mimosa pudica and $C$. gharaf stem bark with a pinch of common salt is boiled in a glass of water and the bark decoction is gargled for relieving pains in gums and teeth [113].

Gogos, Maasai and Kipsigis use a root decoction with milk in malaria [68, 114]. Kara and Kwego people in Ethiopia use root infusion for treating respiratory infection and tuberculosis [33]. Samburu pastoralists in Africa use boiled gum with milk to treat bronchus and pneumonia [115]. The Suiei Doroba tribe of Kenya, use soaked root in water or with honey and soda ashes for curing stomach ache and diarrhea [116]. In Tanzania, roots and bark is used for stomach disorders. Root decoction is used in malaria. Giriamas of Kenya take boiled roots to treat paralysis and inhale steam from boiled leaves under blanket especially for shortness of breath [117]. A Tribe of Angola, West Africa, use pounded roots of Grewia angloensis and CS (=C. gharaf $\mathrm{CG})$ in anemia, common dropsy, hydropsy [118] and branches in setting dislocations and fractures of limbs. Sambarus use a hot decoction of flower in eye infection and malaria fevers [119].

People of Somalia, in chicken pox take handful of fresh CS leaves, boil in water in one liter of and prescribe half a cup three times a day and wash the patient with the decoction [120]. In Randa area, Djibouti, tribals use water soaked with fresh CS leaves as shower bath and in infection diseases [121]. While folks in Senegal use the leaves either alone or mixed with drug-plants, as a fever remedy [122]. Tribals of Ahmednagar District, Maharashtra, use handful of fresh, young and healthy crushed CS leaves with honey, cow ghee and glycerine in cow milk, for cure of mouth ulcer and tongue irritation [123]. 


\section{Use in Male and Female Problems}

Trio is widely used in traditional and folkloric medicine in male and female sexual disorders. The plant parts are useful both in conceiving and also as an abortifacient. The decoction prepared from CD fruits (one cup) taken from $2^{\text {nd }}$ day of menstruation period for three days, helps in conceiving of a woman not getting pregnant. Whereas consumption of $\mathrm{CD}$ leaf paste along with the sun-dried paddy grains helps prevention of ovulation, and thus the eliminating possibility of pregnancy [124]. Folks in Sindh Pakistan, orally give $\mathrm{CD}$ boiled leaves and decoction for prevention of recurrent abortion [88]. CD stem bark is used as abortifacient [125]. People in Africa use CM root decoction to treat malaria which may induce an abortion. $\mathrm{CS}$ roots can also induce abortion [68]. Maasai of Kenya chew the root and swallow the saliva as an abortifacient [120]. Locals in Kasumu, Kenya use CS roots with Ochol (Euclea divinorum) roots as medicine for pregnant women [126].

Trio is also useful in menstrual disorders. Korku tribe, Maharashtra, take stem bark powder with water to cure menstrual disorders [127]. Tribals of Nandurbar and Nasik District, Maharashtra use stem bark decoction for cure of excessive menstruation [128, 129]. Folks in in Somalia, use CS boiled roots to treat dysmenorrhea [130]. Tribals of Nasik district, North Karnataka and Himachal Pradesh eat fruits for treatment of gonorrhea [129]. While in Gujarat leaves are used for this purpose [91].

CD bark and root forms part of formulations for increasing vigor and sperms [100]. People in Orissa and Maharashtra, use CM leaf and fruits for cure of spermatorrhoea and fever [130]. In Dera Gazi Khan, Pakistan, eating of CM fruit before meal is prescribed in treatment of masculine sexual weakness [131]. Green fresh leaves are used in treatment of jaundice and for increasing power in Pakistan and Andhra Pradesh [85, 86].

\section{Use in Agriculture}

Ancient treatise, Brhatsamhita elaborates on use CD (slemstaka) oil as manure [132], while Vrikshayurveda mentions its use for induction of immediate sprouting of seeds [133].

\section{Prediction of antimicrobial/insectidal herb on basis of Ayurvedic determinants}

CD being guru (heavy) and rooksha (dry), soothing (snigdh)/ slimy/picchal in guna (quality); sweet, pungent, bitter and astringent in taste; sweet, katu in vipaka (transformed taste), ushna (hot) and sweet in veerya (potency) [17] possesses all the requisite qualities of an herbal antimicrobial identified earlier [134]. Review of literature on pharmacological testing reveals that CD possesses anti-worm and antimicrobial properties as can be predicted on the basis of Ayurvedic characteristics of antimicrobial plants [134] and is a potential herbal insecticide/antimicrobial as corroborated by pharmacological testing by various researchers (Table-2). Similar prediction for Vitex nirgundi [135] is corroborated by pharmacological testings.

\section{Wood and Timber}

The lasura tree yields, high quality wood, grayish brown in color and weighs nearly 15 to $18 \mathrm{~kg}$ per cubic foot. It is moderately hard, though not very durable for outdoor work, planes well to a smooth surface and takes good polish. It is generally used for making ornamental furniture, house posts, beams, scantlings, planks, dugout canoes, boats, tea boxes, cart shafts, axles, yokes, well-curbs, agricultural implements, combs, gun stocks, naves, spokes, etc. It is also used for making quality toys, bowls and wooden utensils for kitchens for handling sour recipes. The wood, being light and yet reasonably strong, is therefore used to build houses in China, India andfuel wood and charcoal in Philippines [136]. Maher tribe of Gujarat uses CD stem for making 'Dhosari' and 'Ravai'(churning rod) and $\mathrm{CS}(=\mathrm{CG}=\mathrm{CR})$ stem for making 'Kadhamnu' seed drill (Orni), Khapari, handle of Kodari and mill [35].

The timber of CM is soft and light, and not very durable. In Egypt it was used to make horse saddles, while that of CS is a good kindling wood and is considered one of the best for lighting fire by friction. It is used for firewood and for making furniture and tools.

\section{Other Uses}

Marakwet Community in Kenya and people in Oman use twigs of CS as tooth brush [137]. However, Ayurvedic literature forbids use of $\mathrm{CD}$ twigs for this purpose. In Myanmar, the leaves are used as plates and a substitute for cigar wrappers and covering Burmese cheroots.

Tribes in Kenya, India and Tanzania, use CS stems in hut-construction and to construct the fence of the animal enclosure [24, 138] and use bark for covering huts. Gabra people collect wood for house poles at certain ritually prescribed times of the year. Turkana tribe (South Kenya) hollow out the larger pieces into pots [116] and use the hard wood of CS (edome) to make hunting or combat bow. In Ethiopia Kara and Kwego people use branches for making yibet, oar and bee hive [33].

Rural people use the slimy fruit as glue to stick paper and the CD plant owes it name (lekhasataka) to this property [3]. CD stem bark with catechu is chewed as a substitute for paan (betel leaves) to redden lips [108].

Sudanese use brown and slightly scented heart-wood of CS as a substitute for sandalwood. People 
in Burkino Faso, use ash from the young branches as a soap.

\section{Fumigation of Milk Containers}

Maasai and Gabra of Kenya and Rendille of Ethiopia use CS stems and roots for cleaning calabas and smoking/fumigating gourds [139]. Gabra women use dried taproots split into several pieces [140]. This process of cleaning and smoking is known as Qorasum technology (QT) in Kenya. Garba women use QT for preservation of milk and curd and to impart flavour and smell to food and to ensure the proper maintenance of vessels of food storage. It plays a critical role in the preservation of milk, fat and meat products, vital in pastoralist nutrition.

\section{Fuel}

The Mehar tribe of Gujarat uses dried stem of $\mathrm{CD}$ and CS for fire [35], whereas the people of Burkino Faso never use CS for this purpose.

\section{As Ornamantal}

CS has white sweetly-scented flowers and is planted as an ornamental shrub in North Nigeria. In the township of Merca in Somalia it has been planted as an avenue-tree. CS is used for charcoal burning in Kenya that caused decline in plant population [141]. CD is a quick-growing fruit tree, suitable for planting along boundary and farm roads [75].

\section{Nutritional value}

$\mathrm{CD}, \mathrm{CM}$ and $\mathrm{CS}$ fruits are nutritious with additional advantage of high dietary fiber content that plays an important role in decreasing risk of many metabolic diseases. Trio fruits have high calorific value respectively as 684, 281.4 and $318 \mathrm{kcal} / 100 \mathrm{~g} \mathrm{DW}$ and are important sources of dietary calorie.

CD fruit is equally nutritious as banana and guavas (135Rathore, 2009). CD fruit pulp (100 g) contains $35 \%$ protein, $18 \%$ carbohydrate, $37 \%$ fat and 6 $\%$ water while minerals content $(\mathrm{mg} / 100 \mathrm{~g})$ was $\mathrm{Ca}(55)$, $\mathrm{Zn}(2)$, Iron (6), $\mathrm{P}(275), \mathrm{Mn}(2), \mathrm{Cr}(0.2)$ and $\mathrm{Cu}$ (1.6) [143]. CD fruit can fulfill the dietary need of potassium and zinc content [144]. Chromium present in CD fruit has therapeutic value in diabetes.

$\mathrm{CM}$ fruits are a good source of proteins, carbohydrates, phosphorous, calcium, fat and essential minerals as zinc [38, 144-147]. The proximate composition and mineral constituents of CM fruit show $6.7 \%$ ash, $8.32 \%$ crude protein, $2.2 \%$ crude lipid, $25.7 \%$ crude fiber, and $57.08 \%$ carbohydrates. Mineral ranges (mg/100g dry weight, DW) were: K (7.83), Na (1.62), Ca (0.46), Fe (0.51) and $\mathrm{Zn}(0.35)$ [146]

Fruit is rich in sugar contents but but typically acid less in nature. CM fruits contain $(\mathrm{g} / 100 \mathrm{~g}$ of dried product): water 6.21, glucose 12.75, fructose 9.38, sucrose 29.09 and starch 29.09. Ripe CM fruit is sweet because of its high amount of sucrose, d-glucose, and $\mathrm{d}$-fructose, d -rhamose and galacturonic acids. Anti nutrients are in low quantity being 355 phytic acid and $250 / 100 \mathrm{~g}$ oxalate in CD fruits [141] $248 \mathrm{mg} / 100 \mathrm{~g}$ phytic acid and 1.39 (TIU/g) of Trypsin inhibitor content in CM fruits [144].

On basis of a comparative study of the mineral contents of $\mathrm{CM}$ with recommended dietary allowances (RDA), Aberoumand and Deokule [145] suggested that $\mathrm{CM}$ fruit could be a good supplement for nutrients such as fiber, protein and carbohydrates and should be promoted as a carbohydrate and protein supplement for cereal-based diets in poor rural communities.

\section{Phytochemicals}

A number of research workers have analyzed active chemicals that impart medicinal properties to these plants. Various types of chemicals extracted from three Cordias show diverse activities: analgesic, anti-inflammatory, immunomodulatory, antimicrobial, antiparasitic, insecticidal, cardiovascular, respiratory, gastrointestinal and protective effects. Antibiotic-modifying, antinociceptive, antifertility, toxicity, anti-snake bite, hypolipidemic, immunomodulatory and antioxidant. Pharmacology and phytochemical components of the trio and their role has been reviewed [25, 93, 143, 149-153].

CD fruits contain saponins, amino acids, flavonoids, sugar, gum, proteins, and fatty acids as palmitic, stearic, linoleic acids, oleic, arachidic, behenic acids; flavonoids such as kaempferol, quercetin, isorhamnetin, (butanol fraction) and arabinoglucan i.e. D-glucose and L-arabinose, glycosides, aglycone and L-rhamnopyranoside. CD seed contains $\alpha$ - amyrins, betulin, octacosanol, lupeol-3rhamnoside, $\beta$-sitosterol, $\beta$-sitosterol-3glucoside, hentricontanol, hentricontane, taxifolin-3-5-dirhamnoside, hesperitin-7-rhamnoside and fatty acids $[154,155]$.

Fruits of $\mathrm{CD}, \mathrm{CS}$ and $\mathrm{CM}$ show activity on respiratory system disorder while fruits of $\mathrm{CD}$ and $\mathrm{CM}$ reveal antimicrobial, anthelmintic, antioxidant, diuretic and juvenomimitic activity. CD fruit is hypolepidemic, hypoglycemic, shows anti -implantation and hypotensive activity while $\mathrm{CM}$ fruits are astringent, diuretic, demulcent, are cardio-protective and show antioxidant activity (Table-2).

Roots contain Hesperetin 7- rhamnoside, a glycoside of hesperetin Lupa-20, 29-ene-3-o-Dmaltosideand $[149,150]$. CD twigs contain $\beta$--sitosteryl-3 $\beta$-glucopyranoside-6'-O-palmitate, nervonyl 4-hydroxy-transcinnamate ester, and $\beta$-sitosterol [152]. 
CM leaves contain chemicals as linolinic acid, linoleic acid, oleic acid, sitosterol, oleic acid [158, 159] pyrrolizidine alkaloids [159], carotenoids [160]. Leaf extract showed anti-implantation activity, suggesting its possible use as a natural contraceptive drug [161]. Leaves of the three Cordias show anti -inflammatory activity and are useful in digestive system disorders (Table-2).

Table-1: Names of Cordia dichotoma $C$. myxa and $C$. sinensis in various Indian languages

\begin{tabular}{|c|c|c|c|}
\hline $\begin{array}{l}\text { Language } \\
\text { / } \\
\text { Country } \\
\end{array}$ & Cordia dichotoma & Cordia sinensis Lam. & Cordia myxa $\mathrm{L}$. \\
\hline English & $\begin{array}{l}\text { Clammy Cherry, Indian Cherry, } \\
\text { Sebesten Plum, Fragrant manjack, } \\
\text { Snotty gobbles, Glue berry, Pink pearl, } \\
\text { Bird lime tree }\end{array}$ & $\begin{array}{l}\text { Grey-leaved cordia, } \\
\text { Grey-leaved saucer-berry, } \\
\text { woolly saucer-berry }\end{array}$ & $\begin{array}{l}\text { Assyrian plum, Clammy cherry, Glueberry, } \\
\text { Indian cherry, Large sebesten, Sapistan, } \\
\text { Sapistan plum, Sapistan tree, Sebastan tree, } \\
\text { Sebesten plum, Selu, Sudan teak, Dog's } \\
\text { Teat, Indian saucer berm }\end{array}$ \\
\hline Gujrati & $\begin{array}{l}\text { Vado gundo, Barghand, Gundi, Gundo } \\
\text { Vadgunda. }\end{array}$ & $\begin{array}{l}\text { Gundhi, Nana Gunda, Liar, } \\
\text { Gundi, Liyaar }\end{array}$ & $\begin{array}{l}\text { Bargund, Gadgundi, Gunda, Nanugundi, } \\
\text { Pisten, Sepisten. }\end{array}$ \\
\hline Haryana & Laswara, lesua & Guntia, gondi & \\
\hline Pakistan & Bara lasura & & lasuri \\
\hline Hindi & $\begin{array}{l}\text { Bhairala, Bhokar, Chhotalasora, Gondi, } \\
\text { Lasora, Boria Lesuda; bada-goonda, } \\
\text { bara-gunda, bhokar, chokar-gond, } \\
\text { gondi, gonni, gunda, lasoora, lasora, } \\
\text { lasura, lesuwa, lisora, Rasalo }\end{array}$ & Gondhi, Gondni, Gundi & lasora, chokargond, lasua \\
\hline Kannada & $\begin{array}{l}\text { Challe, Challehannu, bankegida, } \\
\text { challebankegida, chikka challe, } \\
\text { chikka-salle, chotte, doda chillu, dodda } \\
\text { changate, dodda solle, haadige, hire } \\
\text { challe, hiri saale, kaadu chaale, kaadu } \\
\text { challe, Kendal, kendala, mannadike, } \\
\text { mannadik, mannadike mara, salle } \\
\end{array}$ & $\begin{array}{l}\text { Jerubonpli, Kadusalle, } \\
\text { kiricalle, Kirichalle, } \\
\text { kirisale, kirikalle, kirisele, } \\
\text { Narevali, narivuli, Nar }\end{array}$ & $\begin{array}{l}\text { challe, chikkasalle, , salle cikkacalle, hadige, } \\
\text {, kaadchellai, kaducalle, kadusalle, , cholle } \\
\text { mannadike, chikkasalle, chikkusalle, } \\
\text { cikkacalle calle, hadaga, cella chella, chelle, } \\
\text { solle, }\end{array}$ \\
\hline Mallayam & $\begin{array}{l}\text { Naruvari, Narunari, Naruviri, naruveeli, } \\
\text { cheruviri }\end{array}$ & $\begin{array}{l}\text { Veri, Verasham, } \\
\text { Pasakaimarum, viri }\end{array}$ & $\begin{array}{l}\text { vida, vidi, vidimaram, virashamvirigi, viri, } \\
\text { virigi, viriyasam, virusham, viruvu, } \\
\text { naruvali, naruveli } \\
\text { Viriyasam naruvili, periya- periya-chettu, } \\
\text { periya-naruvili, periya-viri, valiyvanicci, } \\
\text { valiyavarich, }\end{array}$ \\
\hline Malyali & Valluku maram & & \\
\hline Marathi & $\begin{array}{l}\text { Bekar, Bhokaribakar, bargud, bhakram, } \\
\text { bhokar, bhokara, bhokur, chokri, godan, } \\
\text { goden, gondhen, montabhokar, semar, } \\
\text { shelu, sherti, vargund, vhadli }\end{array}$ & $\begin{array}{l}\text { Bokur, Gondani, } \\
\text { Lahan-selti, Lahan- } \\
\text { Bhakarn Gondhan }\end{array}$ & Gondhen Bohbeer \\
\hline $\begin{array}{l}\text { Rajasthan } \\
\text { Udaipur }\end{array}$ & Umbio, leshwa & $\begin{array}{l}\text { Jungle Bundi(Alwar)Noni } \\
\text { gundhi(Kota) }\end{array}$ & Gonda, Lasora or lehsua \\
\hline Sanskrit & $\begin{array}{l}\text { Bahuvara, shlesh-Malaka, Selu, } \\
\text { Slesmataka, bauvaraca, slesmatakah, } \\
\text { uddalaka }\end{array}$ & $\begin{array}{l}\text { Bahuvarka, Karabudaz, } \\
\text { lagushlemastaka, Shelu, } \\
\text { Slemastaka Bahuvaraka, } \\
\text { Laghushita }\end{array}$ & selu, sukeshmaphala, selluh \\
\hline Tamil & $\begin{array}{l}\text { Uddhala, cavarittakikam, } \\
\text { cavarittakikamaram, cirunaruvili, citam, } \\
\text { jollai, kalliyavam, kalliyavamaram, } \\
\text { kalviricu, kalvirusu, mukku-chali, } \\
\text { naruli, naruvali, naruvalli, naruveli, } \\
\text { naruvili, , naruvuli, perunaruvuli, vidi, } \\
\text { virusham, viruvu, viricu }\end{array}$ & $\begin{array}{l}\text { Nariviri, Nariviran, } \\
\text { Naruvili, Sandanomamani, } \\
\text { Selu, Sirunaruvuli, Irula } \\
\text { Sellai } \\
\text { Masmooki, perunauvulli, } \\
\text { vidi, virusham }\end{array}$ & $\begin{array}{l}\text { Ali, Namviri, Naruvili, Mukku-Chali } \\
\text { ceruvanicci, ceruviri cheruvanicci, } \\
\text { cheruviri, kalvirusu, }\end{array}$ \\
\hline Telugu & $\begin{array}{l}\text { Banka Nakkera, Nekkara, } \\
\text { bankanakkera, bankiriki, botgiri, botuka, } \\
\text { chinna-nakkeru, chinnabotuku, } \\
\text { chinnanakkera, iriki, nakaru, nakkera, } \\
\text { nakkeri, nekkara, pedda botaka, pedda } \\
\text { irki, urunakkera, virigi }\end{array}$ & $\begin{array}{l}\text { Chinbotuku, Chinnabotuku, } \\
\text { Chinnairiki, Cinna botuku, } \\
\text { Cinnbotuku, , cinnbotataku, } \\
\text { cinnavirigi, Nakker }\end{array}$ & $\begin{array}{l}\text { banakarkkiri, banka-nakkera, botuka } \\
\text { chinnabotaku, cinnabotuku, chinnanakeru, } \\
\text { padda-botuka, pedda-nakkera-chettu, } \\
\text { nakeru, nakkera, nakkeri, nakkeru, nakkiri, } \\
\text { nekkara, nekra, urunakkera, iriki, irkee, irki, } \\
\text { vura-nakkheru. }\end{array}$ \\
\hline Arabic & Dabak, Dabk & Underab & $\begin{array}{l}\text { Sapistan, Alpmbr tree, Alpmbr - sewn - } \\
\text { Alhambo - Gao - gauge BD , dabk, } \\
\text { Mujayta, mujaytā, mujaytī, mujatà }\end{array}$ \\
\hline
\end{tabular}




\section{Cordia dichotoma}

Assamese: Goborsuta Goborhut, bahubara, Bangla: Chhotobohnari, Buhul or Lashora; Chhatisgarhi: Lasua; Dogri: Lasura; Uriya: Amobhoto, Gondi; Manipuri: Lamkelaba; Meghalaya Khasi: Dieng Mong; Mizo: Muk-fang; Punjabi: Laswara; Mallayal: Valluku maram; Tribals: Miris: Sirma, Siumang; Lodhas: hemrum, Santal: buch, Gonds: Bohar; Handia and Maria: Bohbeer; Tibii/Unani: Sapistan, Dabak, Babak; MP: Debdaru.

Bangla Desh: Kalhuza, bohari, Bella, Chaine (Mogh); Bol-mimang, Thakaksum (Garo). Kalahuza, (laleng, Partha), Bonary, Bohari; Bohal, Buhal (Chittagong); Aslia, Kalahuza (Sylhet). Bongol gaas (Chakma); Chinese: Po Bu Zi Ye, po bu mu, Feng zheng Zi, shuai, bu zi, po bu ye, lan bu (zi)zha, bu bao mu, po bu shu, xiang bo ye, Shù zǐ zăi; Uighur China: Pobumuguo; Japanese: Husayou; Lao (Sino-Tibetan): man, 'man khôk; Malaysia: Sekendal, Sekendai, Petekat; Mayanmar Karen People: Thanat; Nepali: Bohori, Kalo bohori; Pakistan: Sindhi: Giddori, Lessori; Pusto: Lasora; Persian: Sapistan, Suspistan; Thai: Mandong, Manma, Phakmong;

Phillippines: Tagalog: Anong, anono, Anonang bakir, Anonung, Anunong, Saloyong;

Ifugao: Anunong; Bisaya: Anunong; Sulu: Guma, nunag; Ibanag: Anonang; Iloko: Anonang, anonag-bakir, sinaligan; Bikol: Anonang; Bikano: Anonang; Manasaka: anonan; Maranao: nonan; Cebuano: anunan;

Indonesia: (Balinese): Korean: posayep; Javanese: Kendel; Malay C (Indonesia): Manonang, Nimang Sekndai, Sekendal, Tomatangtang; Manggarai: nunan; Rembong: nunan; Halmahera: Toteolo; Sumatra, Malay: Nunang;

Taiwnese Chinese: Chhiū chí á. Phòa pò chí.; Paiwan: Adodan, Baaryuu; Atayal : Tatugatum; Bunun: Pananun; Formosan: qaNuNan; Keyu Hakka: Lan bu zìi. Lan2 bu2 shu2;

Vietnamese: Thiên đầu thống, Ong bầu, Trái keo 1 [as] b[aj]c, 1[as] tr[aws]ng Tác dụng của, thành phần của; French: Sébestier dichotome, capestan; Russian: Kordiia indijskaia, Kordiia vil'chataia.; Paraguay: Petereby; Papua New Guinea: Cordia

\section{Cordia Sinensis}

Ethiopia: Malló mucci: shengolochi (M); Kara: midir, togoz; Kwego: chuwacho; Bo: ubacho, ulicha, underab (A); Galinya: maderra; Somali: Koha, Mahrari; Djibouti (Randa): Maderto(Geez?); Sudan: Ama / Nyman: Kabide; Dinka: Akoc, Akuei, Akoy; Nuer: Nyot; Andrab, Andarab; Kenya: Samburu: Borena: Harores, mader-b, Madheer raphachoooor, madeer-qoowe, madee'r, Maderboor; Chonyi: mkayukayu; Gabra: mad'eera ; Giriama: mderia, kayukayu; Ilchamus: salapani, lgweita; Kamba: kithea, muthei-munini, kithia; Kasigau: izera; Kipsigis: nokirwet; Konsogna: Maderta; Maa: ol-durgo, ol-dorko, ol-olgot; Dry bushland: Malakote: Madera, Mutalya-naja Orma: mader, madera; Somali: marer mareer,; Riverine forest: Malakote mutalya-chana, mutaale; Orma: Kote; Somali: : marer-khoh; Tana Marakwet: Adomoyon, Adomeyon; Pokomo: muhale, mhali, mtale; Pokot: adomeyon, adomeon, adome (fruit) katuntulion; Rendille: gaer, koh, madeer, gayer, gaeer; Samburu: lkweit, Igoita; dorgo, manturre, lgueita, lgweita-orok, silapani; Sanya: ho'orocha; Tugen: adumewa, edoma (leaves), adomewa, Adomeyo; Turkana: edome; Swahili: Mnya, mate, mkamasi; Giriama of Basi: Mkayukayu; SuieiDorobo: silapani (lgweita); Rendille (Marsabit district. K): Lgoita; Wardei: Marer; Chad (Zaghawa): Andarab, turu;

Umbundu Angola: Angola: (olo) ngombe, (omu) puka Umbundu; Namibia: (omu) koyo, (omu) tua-koyo (Nyaneka); Mozambique: cambununo, duva; Namibia: Oshiwambo: Kaliko; Otjiherero: Omusepa; Omupombo, osepa omusepa, Omuzipa; Caprivi: Muliza; Oshiwambo, Oshikwanyama: omiku yumbwa O-Ok; Khukh Namibia: es, is, khos; Kwanyama (Namibia): omiku yumbwa, omupombo; Afrikaans N: Langblaarpiering bessie; Damara/Nama (Namibia): aes, nai; German N: Schleimbeerenstrauch.;

Afrikaans SA: grysblaarpieringbessie; Tsonga SA: mpon'wana, mtlele; Tswana: mwarasupe; Venda SA: mutadola; Lunyaneka: omukoio; Kwanyama: omuku yumbwa; Konsogna: Madertta (Konsogna);

Somalia: mareer; Mauritania: 'Maine'A akjül (Aub.); Senegal: Maure'A) akjül (Aub.); Serer(Senegal): Subduam, suo mâg; Wolof Sene: Mbey mbey, nehneh, tâpus; Mali Songhai: Barmadangaïe, fifrigui; TamachekMali: tadanu; Ghana: gonyont ; Arabic Niger: hen'darabaïe; Southwestern Niger: barmandagaye; Hausa Niger: tedanat, tidani; Kanuri Niger: Kabulu, Kabula; Tamachuk Niger: Tadanu; Tubu Niger: Kohul; Arabic Nigeria: Inderab; Hausa Nigeria: tadana, tidani; Kanuri Nigeria: kabilla; Nigeria: Hausa: Tadana, Kanuri Niger: Kabilla; Zarma: Fifrigi; Niger WA: bomo-dangay (Zama); Niger: /Wadaabe: dornohi;

Tanzania: Habusu, ngheghi; Filome: baghalmo-lambi; Gogo: mdawi, mdawisogwe; Gorowa: hanarmo; Hehe: Mdawi; Iraqw: Bagalimo; funidang, hararmo; Maasai: oldorko, olofot, oldurgo, oldurogo; Mbugwe: mochocho; Nyamwezi: mlembu, mnembu; Nyaturu: mdumwa-kiguu; Pare: Mpololo; Hehe: Mdawi; Hadza: undushipi, kisinubi; Rangi: mnembu; Iraqw: bagharimo, funidang, hararmo; Swan: mkamasi, nyamate; Tanzania: edorko; mudawe; Sandawi: angweegwee; Swahili: mkamasi, mnya mate. 
Wood Names: Swahili: Nyamate; Indonesia: Salimuli; Mal, kalamat, Papua New Guinea: Keroseni wood, Cordia, Island wood; Philippines: balu anonang; Mayanmar: Sandawa; Thailand: mamlong, kalamat; Kenya: Muthea; Boarno Euthopia: Madheera-raphachoo

\section{Cordia myxa L.}

Crotian: asirijska šljiva; German: Brustbeeren; Greek: Myxia (Cyprus).

Hungry: asirijska šljiva; French: Capestan, Bois savon, Prunier d'Assyrie, Sébeste (fruit), Sébestier (tree), Sébestier domestique, Sébestier mixa, Sébestier officinal, Sébestier vrai; Italian: Frutto di visco, Tibisco; Portugese: Sebesteira, Sebesteiro-do-Sudão: Russian: Kordiia miksa, Kordiia slizistaia; Spanish: Ciruelo asirio; Tibet: Sle ma sma ta ka; Euthopia: Galinya: marad, madad; Ghana: Lobotilli gbli, tungbo; Guinea: darama, degue, darama, ndeke, ndien, ntu, sanadjo;
Ivory Coast: darama, clede, lobotili gbli, ndele, tia, manohi; Mali: colle, darama, daramba, degue, daramba, ndarma, ndeke, ndike, tiamanobi, tungue'; Senegal: darama, darama tunko, degue, daramba, mbey, mbay-gile, narr, ndege, nedeke, sub, subdjuam, tamanohi, tamus; South Africa: muTsikiri(shona); Upper Volta: ndeke, tango, tunguo;

Indonesian: Kayu semang; Malaku island Indonesia: Ai Huluti;

Spanish castellano: sebestén

Iraq: Banbar, Bumber; Kuwait: Bambar; Pakistan: lasuri Urdu: dabk, sapistane-kalan, moklat-ahe-kabur, sugpistan; Persian: Sepistan, Sebestan or sapistan, dogs' dugs.

MP: Labhera, Lasora; Punjabi: Lassora, Lasūṛā, Lasūṛhā; Unani: sapistane-kalan, moklat-ahe-kabur, sugpistan.

Table-2: Pharmacological Activity of Cordia dichotoma, $C$. myxa and $C$. sinensis

\begin{tabular}{|c|c|c|c|}
\hline & Cordia dichotoma & Cordia myxaL. & Cordia sinensis \\
\hline \multirow[t]{15}{*}{ Fruits } & Anthelmintic $[198,199]$ & Antioxidant [219] & $\begin{array}{l}\text { Antioxidant, Anti-Glycation } \\
\text { Anti-Inflammatory [233] }\end{array}$ \\
\hline & Wound healing [200] & $\begin{array}{l}\text { Antioxidant, hepatoprotective chemically } \\
\text { induced fibrosis [219] }\end{array}$ & \\
\hline & Hypolepidemic effect [79] & anti-inflammatory [220] & $\begin{array}{l}\text { Immunomodulator } \\
\text { [234] }\end{array}$ \\
\hline & Antimicrobial [93] & Gastroprotective [221] & \\
\hline & $\begin{array}{l}\text { Analgesic, antibacterial, cytotoxic } \\
\text { [201] }\end{array}$ & cardioprotective plant extract [222] & Antitubercular plant extract [111] \\
\hline & Degenerative disorder [154] & analgesic, antiinflamatory [223] & \\
\hline & Anti-inflammatory [202] & & \\
\hline & Antioxidant activity [93] & & \\
\hline & Gastroprotective antiulcer [203] & Immunomodulator [224] & \\
\hline & $\begin{array}{l}\text { Hypotensive \& respiratory } \\
\text { stimulation [204] }\end{array}$ & Anti lesmanic MUCILAGE Extract [225] & \\
\hline & Antipyretic [73] & & \\
\hline & Antidiabetic [205] & & \\
\hline & Antimicrobial [206] & & \\
\hline & Diuretic [207] & & Cardioprotective [225] \\
\hline & Untiulcer [208] & & acute inflammation [226] \\
\hline \multirow[t]{9}{*}{ Leaves } & Antifertility $[208,143,161]$ & Analgesic and anti-inflammatory [226] & \\
\hline & $\begin{array}{l}\text { Hypoglycemic, } \\
\text { antihyperglycemic }[5,28]\end{array}$ & Analgesic and anti-inflammatory [227] & Wound healing [236] \\
\hline & Anthelminth $[143,161]$ & & \\
\hline & $\begin{array}{l}\text { Antibacterial' Antimicrobial [143, } \\
\text { 161] }\end{array}$ & & \\
\hline & Analgesic $[143,161]$ & Antitumour [228] & \\
\hline & Antiglycemic $[143,161]$ & & \\
\hline & Antiulcerogenic $[143,161]$ & & \\
\hline & Antitermite [209] & & \\
\hline & Antidepressant activity [210] & & \\
\hline \multirow[t]{7}{*}{ Bark } & Ulcerative colitis [211] & Antihelmintic [227] & \\
\hline & Antimicrobial; antifungal [212] & & Cardotonic, stem bark antidiabetic [149] \\
\hline & & Insecticide $[48,230]$ & Antimicrobial, anticarcinogenic [235] \\
\hline & Antioxidant [93] & & Antibacterial [237] \\
\hline & Analgesic [213] & Anxiolytic [231] & \\
\hline & Anti-implantation [214] & & \\
\hline & Antioxidant nariya [215] & & \\
\hline \multirow[t]{2}{*}{ Seed } & Wound healing [216] & & \\
\hline & Antioxidant $[28,217]$ & Astringent [232] & \\
\hline $\begin{array}{l}\text { Seed \& } \\
\text { leaf }\end{array}$ & Antimicrobial activity [218] & & \\
\hline
\end{tabular}




\section{Cosmetic}

Ayurvedic treatises have recommended use of Cordia for skin [17]. CD plant extract is used in cosmetic and pharmaceutical compounds for the treatment of skin aging. An aqueous extract of the plant inhibited the elastase activity. An anti-wrinkle cosmetic gel contained Cordia dried extract. US registered a patent no. US 6238674 B1 [162] for use of extract of C. dichotoma as "A method of treating a human body for delaying effects of aging on skin thereof, by applying to a part of the skin in need thereof of a cosmetic or pharmaceutical composition containing an amount of an extract of $C$. dichotoma effective to inhibit activity of elastase in the skin, obtaining thereby the delaying of the effects of aging on the skin" [163] suggested use of $C$. myxa in preparation of topical cream, because of pharmacological effects such as ant-inflammatory activity.

\section{Gum as a Binder}

The CD seed mucilage gum is can be used as a binding agent in the conventional tablet formulation. It has greater potentialities to become the new source of binder and could also be exploited for the commercial production of gums [164] Cordia species fruit mucilage has potential for many pharmaceutical applications as an anti-capping agent with different binder, tablet binder, emulsifier, for sustained control of delivery system through transdermal film, micro particulate and nano-particulate delivery system [165].

Cordia dichotoma fruit mucilage (CDFM) appears to be suitable for use as a release retardant in the manufacture of prolonged release matrix tablets because of its good swelling, good flow and suitability for matrix formulations. Dried (CDFM) can be used as an excipient for making prolonged release matrix tablets. Gum cordia (C. myxa) can substitute the synthetic polymers as HPMC in preparation of buccal tablets so useful in dentistry as powdered mucilage significantly effects the tablet characteristics, and increasing in muco-adhesiveness [166].

Cordia gum can serve as a good option as bio-degradable, cheap, economic and easily available emulsifier in pharmaceutical excipient and could compete favorably with gelatin as binder in tablet formulations due to its good bio-adhesivity [167]. It is good option in preparation of transdermal patches microspheres and nano-suspension formulation in ophthalmic delivery of fluconazole. The Cordia gum may also be a suitable option as an excipient for matrix forming agent to impart enteric resistant and sustained drug delivery in tablet.

\section{As glue}

The pulp of half ripe fruit can be used as an alternative to paper glue in office work. Manabos and
Cebuanos tribes of Philippines and people in Assam and Mahers of Gujarat use the gelatinous substance of CD fruit as gum for pasting cardboard and paper sheets [2, $35,168]$.

\section{Coating Pine nuts}

Gum coating increases shelf life of Pine nuts (Chilgoza, Pinus gerardiana). It is a rich source of unsaturated fatty acids and the un-shelled nuts are highly susceptible to rancidity. Coating with Gum Cordia containing CM extract exhibited highest (ca. 95\%) increase in shelf life. While, samples treated with alpha tocopherol did not improve the oxidative stability [169].

\section{Fiber Source}

New natural cellulose fabrics identified from CD branches possess structure and their properties suitable for blending and processing with biodegradable polymers to make green composites for various types of applications [170].

In Sudan CS (=CR) is one of the 13 used species for fiber extraction. Most of the extracted fiber is used locally or traded outside the production area as raw or processed products [171] The inner bark of CS is fibrous and a fibre can be extracted to produce strong cordage and caulking material for boats and paper pulp [122].

Bark is used for making ropes utilized locally used for building huts, bed making, well lining, and livestock tying. Bast from CM in the Philippines, and that from CD and CS is used to make rope $[122,170]$.

\section{Corrosion Inhibition}

Alcoholic extracts of stem, leaves and fruits are effective for corrosion inhibition activity in acidic media for mild steel and aluminum and activity is attributed to the alkaloid allantoin and flavanoids that are cause of inhibition activity [172].

\section{Dyes}

C. dichotoma bark gives red dye on fabric with alum as mordant [173]. Leaves, roots and fruits yield yellow and red dye $[173,174]$. The bark contains $2 \%$ tannin and finds use in industry [175].

\section{Coppicing ability}

$\mathrm{CM}$ and CS are fast growing and plants possess good coppicing ability. The coppicing is a very effective and fast growing method for producing timber, fuel wood, fodder and other products of plant without replant and may be very useful to achieve the goal of demand of the people of village community $[25,176]$.

\section{Cordia in Folklore}

Lasora has penetrated the folklore because of its multifarious uses. Many villages in India owe their 
names to this plant as village Lasoda, in Swai Madhopur, Jaipur. Bahuvara of Mirzapur district UP appears in historical records being given in charity by the King. A great sage and teacher of Vedanta owed his name to Uddalaka also known as Uddalaka Aruni. Gundia, a Bhil clan of Rajasthan, owes its name to Cordia gharaf (CS) [177].

$\mathrm{CD}$ is the provincial tree of Phra Nakhon $\mathrm{Si}$ Ayutthaya Province of Thailand. An African country, Burkino Faso issued a philatelic stamp in 1977 showing wild fruits of $C$. myxa. Here, the Bobo people consider its wood too sacred to burnt [178].

\section{Proverbs}

People of Rajasthan, India, discriminate CD and CS as is evident from folk saying 'Karam futya re kesva, gundi ke lagya laswa' ie. When fortune frowns the unprecedented may happen like a tree of gundi bear fruits of leswa. Separate common names for two species are prevalent in number of vernacular languages [179].

In Kannnda, 'Challehannu thinsidra?' means asking the other "were you conned, (persuaded by deception) ?" [180]. Challehannu means Cordia.

Punjabi language uses Lasoda as a medium to convey the human nature 'Ākar cure dī les lasūde $d \bar{\imath}$ 'literally it means 'Arrogance is identified with a sweeper/low caste and the stickiness with Cordia'. It is said so 'When some low person is arrogant / proud'

In Hindi, lasora is a simile for big eye. In Jain literature, Cordia fruit is symbolic of eye balls as elaborated by an incidence wherein a raged king who was blind asked the soldiers to take out eyes balls of all the culprits and asked to keep these in a tray. The soldiers instead of eyeballs placed the tray filled with Cordia fruits. The blind king frequently touched these and cherished the touch.

CS appears in pre-islamic Arabic poem by Al-DamyatI, Mujam Asmd^ al-Nabdtdt, Cairo 1965, identifies the botanical items gharf (1.2); Cordia gharaf [181].

\section{Use in Rites de passage and Cultural Beliefs}

People of Manabo Abra province in Philippines use CD leaves decoction for bathing a new-born child and its mother. In India, in Horaray Asrology, plant is associated with planet Jupiter and Svati nakshtra, however, some associate this nakshtra with Terminalia arjuna [182].

In East Africa, CS is widely used in rituals of Gabra, Samburu, Masai and Boran tribes of Kenya, Maasai of Tanzania and Rendille of Ethiopia. Gaayer (CS) is the most important tree of the Rendilles, due to its numerous practical and ritual uses. It is highly imprudent to carelessly step over the stick (made of CS) of certain men when it is lying on the ground. During transportation of new house to a new settlement site for the first time, a gaayer twig is pinned on top of the load of the camel bull used for this purpose [137].

Samburu and Rendille spread branches at site of building the house of newly married couple, branches are also put above the house during almadho and soriyo ceremonies. Maasai use CS sticks to settle the disputes and to stop a fight or to prevent oneself from being attacked; a stick is placed between the opposing parties. In Gabra, Northern Kenya, like all married men, $a d$ ' abrella (ritual expert) carries a stout shepherd's staff made of from this ritually significant tree. This tree is most commonly used in Gabra country and furnishes wood for making of mens' and womens' marriage sticks (the herori and siqqe). In Oramo these sticks are linked to the origin of institution of marriage [183].

Among the Dhaasanac of South-West Ethiopia, the tuurperim (priest) have paramount ritual importance, both in war and during the dimi ceremony as in which the ritual tree called mier (Singulative: miedi) (C. rothii or sinensis) is cut [184].

\section{Symbolic Uses}

In Western Africa, CM is charged with magical and religious meaning and used in mourning rituals [45]. Such symbolism could also have existed in Egypt, where Cordia is mentioned in various funeral contexts until Pre -dynastic times [19]. Endocarps are reported in Pharaonic (Thebes; 12th dynasty) and Roman (Douch, Hawara) funeral sites [6]. The symbolic meaning of Cordia could then have crossed the Mediterranean Sea as [104] recorded Cordia in the cremation grave from Ni^mes, Avenue Jean Jaure`s in France, and concluded its use as a plant offering, and as an indication of high social status or for its cultural/symbolic value.

Among Gabra of Kenya and Rendille of Ethiopia CS is also used in the camel trust system. Rendille deposit a twig of gaeer (R) madeer (b) in the house of the camel donor as a ritual payment $[185,186]$. At the time of asking favor for a camel mare the borrower is required to give a gift to the giver a gaayer twig and grease his head. These are two symbolical benefactions meant to put moral pressure on the potential giver.

\section{Taboos}

Vrikshayurveda of Surpala, and Vishvavallabha forbade planting of sleshmataka and some other trees considered inauspicious near residence of a happy person or in home gardens $[15,133]$. While Manasollasa goes on to say "the Kings wishing welfare must never plant in a garden, trees like Butea monsperma, Bauhnia variegata, Tamarindus indica, Cordia dichotoma, Terminalia arjuna and Pongamia 
pinnata" [16]. In Mahabharata, the use of long bottle gourd, Kalasaka (curry leaf), Slemastaka, Sudersana(?), leaves of Bamboo or Karira (Capparis decidua) is interdicted [187]. Manusmriti, Manava Dharmasastra [188] advises that "One should carefully avoid red exudation from trees and (juices) flowing from incisions, the Selu (fruit), and the thickened milk of a cow (colestrum)"

Cordia was used at the time of sacrifice. In the great horse sacrifice of the Ramayana, twenty-one posts were erected, six made each of Vilva (Agle marmelos), Khadira or Acacia, six of Palasa (Butea frondosa), one of Udumbara (Ficus glomerata), Sleshmataka (Cordia f), and one of Devadru, the Deodar pine tree [189].

\section{Disadvatange}

As referred earlier, in Taiwan pickled fruit (with stone) is used as an appetizer. The sticky pulp and indigestible seeds of this fruit can form a phytobezoar if ingested excessively. Phytobezoars are classically found in adults with a history of previous gastric surgery, conditions of reduced gastric acidity, poor gastric mixing, or delayed motility [190].

\section{DISCUSSION}

Hippocrates nearly 2500 years ago said so "Food is the medicine and medicine is the food" and (Proper diet is the medicine and there is no medicine like proper diet). Even good medicines will not cure a patient without an appropriate accompanying diet. Cordia species fit into the Hippocratic criteria of food being a nutraceutical food having therapeutics activity against a number of ailments.

Cordia apart from being traditional and famine time food possess many advantages as having good nutritional value due to presence of minerals. A comparison of nutritive value and energy obtained of commercially available fruits viz. apple, banana, grapes [191] with wild fruits reveal that Salvadora oleoides, Cordia dichotoma and Carissa carandas are nutritionally superior [142, 148]. Consumption of Cordia in sufficient amount could contribute greatly towards meeting human nutritional requirement for normal growth and adequate protection against diseases arising from malnutrition [142]. It has been suggested that the nutritive values (NV) of the wild edibles are good and in many cases superior to conventional food resources [192] and the statement stands true for Cordia also.

In addition to food, the three Cordias (referred as trio) have multifarious uses. Trio may serve as forage plants, fodder for cattle, and goats and a green source of dye, fodder, fiber, and a corrosion inhibitor. CD is one of many recommended trees that can stand against dust pollution [193]. However, its tolerance to stand tannery effluent is low in comparison to Acacia nilotica, Ficus religiosa, Pongamia pinnata and Cassia auriculata [194]. CD is a good fodder, but generally used on a small scale more so during grass famines though available most of the year. A high proportion of fatty oils and proteins in seed kernels (46 and 31\%, respectively) make these potential source as cattle feed [68]. Feed supplementing with $\mathrm{CD}$ leaves increase body weight gain in lactating buffaloes without affecting the milk yield and composition and reduces methane production $[54,55]$.

Cordia fruit mucilage has potential for many pharmaceutical applications as an anti-capping agent with different binder [164], tablet binder, emulsifier, for sustained control of delivery system, through transdermal film, microparticulate and nano-particulate delivery system.

Folkloric use of Sleshamatak in cattrah, cough and cold, fever, pain, skin diseases, urinary problems, inflammation, jaundice, wounds, toothache, kidney stone, hepatitis, sexual weakness is based on its use in traditional systems. In Uighur medicine, healers use Abnormal Savda Munziq (ASMq), an herbal formula composed of 10 medicinal herbs including $\mathrm{CD}$ as an important component [64] for preventing cancer, diabetes, cardiovascular disorders, and chronic asthma [72]. Some of the pharmacological activities proved in pre-clinical trials (Table-2) confirm Ayurvedic uses of Cordia as diuretic, antipyretic, analgesic, anti-inflammatory, wound healing, astringent, anthelminthic explained in old texts conveying good knowledge of the ancient sages.

A perusal of table on indications for various disease condition prepared from 8 Nighantus reveal [17] that $\mathrm{CD}$ is listed in 7 as varnya (cosmetic, aid to complexion), followed by kushtghna (eliminates skin diseases, antiscorbutic), krimighna (anthemintic), and visarpa(erysiphales); vishghna (anti-poison) and vishphot (herpes zoster, shingles), Masurika(small pox); kusht (leprosy killer), keshya(promotes hair and hair health), malavrodhak(constipation), as amavicar(ama is toxin produced in body by undigested food that become fetid, vicar=disorder), shool (stomach pain), mutrakrish(in dysuria and difficulty of passing urine).

Karami et al., [163] prepared a cosmetic cream from $\mathrm{CD}$ and American patent office has issued a patent for anti-wrinkle gel based on CD extract. These two instances corroborate and speak high of the practical knowledge saved in ancient Indian treatises.

Main hindrances in popularity of these small berries include unavailability of high yielding varieties, low keeping quality of ripe fruits that restrict its transportation to far off places, better post harvest handling technology such as atmosphere packing methods to extend shelf life and further extend 
Ahuja, S. C et al., Sch Acad J Biosci, July, 2020; 8(7): 187-209

marketing opportunities. Unripe lasora is easy to find in season as it transports well, making them prime for distribution to far-off markets because of its popularity in traditional dishes [2]. Varietal improvement programs on $\mathrm{CD}$ and $\mathrm{CM}$ are in progress in India and Kuwait. Central Arid Research Institute has released two elite genotypes, CAZRI-G 2021 and CAZRI-G 2025 of $C$. dichotoma, with consistent fruit yield $(59.5 \mathrm{~kg}$ and 98.2 $\mathrm{kg}$ ) and pulp content [54]. There is urgent need of studies for introduction of better post harvest handling that can help to maintain the freshness of the fruit and enhance its competitive marketing edge. Some practices recommended so far include harvesting fruit at yellowish green stage to maintain fruit weight and minimize shriveling, plucking fruits with stalk and packing in bamboo basket. Modified atmosphere packaging studies supported with fruit biology and physiology are also needed to extend the shelf life of the fruit [194].

People in tribal areas still use many of wild fruits as a supplement of their basic food needs; however, the present generation is unaware of its importance. The dependence \& popularity of these nutraceutical wild fruits has gradually declined with introduction of exotic fruits (olives, black berries, crane berries, avocado and broccoli) coupled with undue advertisement and favor by modern chefs on food channels have pushed our valuable plants far behind. Another threat posed is expanding area under urbanization.

Unfortunately, $\mathrm{CD}$ is now listed as an underutilized fruit [195] while $C$. myxa L. and $C$. sinensis $(=C$. rothii) respectively as a vulnerable taxon and a threatened species in India [196]. Hence onus comes to natural resource-experts to find out way to conserve and utilize these valuable nutraceutical fruits. As a remedy, a wider and sustained acceptance of wild fruits as important dietary components must be stimulated. For value addition, efforts on part of Governmental agencies, Institutes, research scientist, pharmaceutical companies, should be directed to increase ways of added and increased utilization on dietary uses, and production. For this immediate need would be on concerted efforts towards clinical trials to confirm multitude of pre- clinical results and to put these to production level through increased demand from industry and creating awareness among young generation regarding its potential.

\section{REFERENCES}

1. Hutchinson J. Cordia myxa and Allied Species. Bulletin of Miscellaneous Information, (Royal Botanical Garden, NY.), 1918; 7: 217-222.

2. Parmar C, Kaushal MK; Cordia obliqua. In Wild Fruits of the Sub-Himalayan Region, Parmar C, Kaushal MK editors, Kalyani Publishers, New Delhi, 1982; 10-12.
3. Sharma PV. Namrupajnana- Characterisation of medicinal plants based on etymological derivation of names and Synonyms. Satyapriya Prakashan, Varanasi, 2000.

4. Kueffer C, Mauremootoo J. Case Studies on the Status of invasive Woody Plant Species in the Western Indian Ocean. 3. Mauritius (Islands of Mauritius and Rodrigues). Forest Health \& Biosecurity Working Papers FBS/4-3E. Forestry Department, Food and Agriculture Organization of the United Nations, Rome, Italy; 2004.

5. Cordia dichotoma G. Frost.-plant list http: //www.theplantlist.org/tpl/record/kew-2736712

6. Kislev ME. Archaeo-botanical evidence of birdliming at Ashkelon. In Ashkelon 1. Introduction and overview (1985-2006). Stager LE, Schloen JD, Master DM. editors, Eisenbrauns, Winona Lake, 2008; 131-137.

7. McCann C. Trees of India. Taraporewala Sons and Co.Ltd. Bombay; 1959.

8. Cordia myxa L. The plant list http: //www.theplantlist.org/tpl/record/kew-2737033.

9. Cordia sinensis http //apps.worldagroforestry.org/treedb2/speciesprofil e.php?Spid=18108

10. Kirtikar KR, Basu BD. Indian Medicinal Plants, $11^{\text {th }}$ Edition, Vol 3, Orient Enterprises; 1935.

11. Cordia sinensis Lam. The plant list http: //www.theplantlist.org/tpl1.1/record/kew-2737232

12. Arora RK, Nayyar ER. Wild relatives of crop plants of India. National Bureau of Plant Genetic Resources (NBPGR), Kapoor Art Printing Press, New Delhi, India; 1984.

13. Balapure KM, Maheshwari JK, Tandon RK. Plants of Ramayana. Ancient Science of Life. 1987; 7(2): $76-84$.

14. Sharma PV. Fruits and vegetables of Ancient India.Chaukhamba Orientalia, Varanasi, Uttar Pradesh, India; 1987.

15. Sadhale Nalini. Vishvavallabha (Dear to the World) (translation). Agri-History Bull. No.5, Asian Agri- History Foundation, Secunderabad; 1987.

16. Sadhale Nalini, Nene YN. Bhudharakrida (Royal Enjoyment on Pleasure -mound) in Manasollasa. Asian Agri-History. 2010; 14(4): 319-325.

17. Sason R, Sharma Anita. The Phytochemical and Pharmacological Properties of Cordia dichotoma: A Review. Ayushdhara. 2015; 2 (3): 155 -161.

18. Strabo. The Geography of Strabo, Translated by HL Jones, Loeb Classical Library, Heinemann, London; 1932.

19. FahmyAG. Missing plant macro remains as indicators of plant exploration in Predynastic Egypt.Vege. Hist. Arecheobot .2005; 14: 287-289.

20. Shamasastry R. Kautilya's Arthasatra. Government Press, Bangalore; 1915.

21. Kislev ME. Vegetal food of Bar Kokhba rebels at Abi'or Cave near Jericho. Rev Palaeobot Palynol. 
1992; 73: 153-160.

22. Van Zeist W, Bottema S, van der Veen M. Diet and vegetation at ancient Carthage, the Archaeobotanical evidence, Groningen Institute of Archaeology, Groningen; 2001.

23. Kajale MD. Plant Economy. In Excavations at Inamgaon. 1(2), Dhavalikar MK, Sankalia HD, Ansari ZD editors, Deccan College Postgraduate and Research School. Pune, India.1988; 727-821.

24. Hines Deborah A, Eckman Karlyn. Indigenous multipurpose trees of Tanzania: Uses and economic benefits for people. Cultural Survival Canada and Development Services Foundation of Tanzania Also Distributed by Tree Roots Canada; 1993.

25. Hussain N, Kakoti BB. Review on ethno botany and psychopharmacology of Cordia dichotoma. J Drug Deliv Ther. 2013; 3: 110-113.

26. Kanodia KC, Gupta RK. Some useful and interesting supplementary food plants of the arid regions. Journal d'agriculture tropicale et de botanique appliquée. 15(1-3) : 71-74.

27. Gaurav S, Navneet N, Sandeep R, Singh P, Porwal A. Effect of aqueous leaves extract of Cordia dichotoma on blood glucose levels of normoglycemic \& alloxan induced diabetic Wister rats. Int J Pharm Res Dev. 2010; 2: 13-14.

28. Hajra PK. Baishya AK; Ethanobotanical notes on the Miris (Mishing) of Assam plains. In Contributions to Ethnobotany of India. Jain SK editor, Scientific Publishers, Jodhpur. 1981; 161-169.

29. Vartak VD. Some Wild edible Plants from the hilly region of Poona District, Bombay state. Journal Bombay Natural History Society. 1959; 56(1): 8-25.

30. Gueye M, Ayessou NC, Koma S, Diop S, Akpo LE, Samb PI. Wild Fruits Traditionally Gathered by the Malinke Ethnic Group in the Edge of Niokolo Koba Park (Senegal). American Journal of Plant Sciences. 5: 1306-1317.

31. Nedi T, Mekonnmen N, Urga K. Diuretic effect of the crude extracts of Carissa edulis in rats. J Ethnopharm. 2004; 95(1): 57 -61.

32. Khyade MS, Kolhe SR, Deshmukh BS. Wild edible plants used by the tribes of Akole Tehsil of Ahmednagar District (Ms), India. Ethnobotanical Leaflets, 2009; 13: 1328-1336.

33. Teklehaymanot T, Giday M. Ethnobotanical study of wild edible plants of Kara and Kwego semi-pastoralist people in Lower Omo River Valley, Debub Omo Zone, SNNPR, Ethiopia. Journal of Ethnobiology and Ethnomedicine. 6: 23.

34. Kapoor A, Kanwar P, Gupta R. Traditional recipes of district Kangra of Himachal Pradesh. Indian Journal of Traditional Knowledge. 9(2): 282-288.

35. Odedra NK. Ethnobotany of Maher Tribe in Porbandar District, Gujarat, India. PhD Thesis, Saurashtra University. 2010; 459 pp.

36. Shankar Vinod. Life Support Species in Indian
Thar Desert. In Paroda et al. Editors, Life Support Species: Diversity and Conservation. National Bureau of Plant Genetic Resources. New Delhi, 1988; 173-180.

37. Chauhan Deepti, Shrivastava AK, Patra Suneeta. Inter Diversity of leafy vegetables used by tribal peoples of Chhattisgarh, India. International Journal of Current Microbiology and Applied Sciences. 3(4): 611-614.

38. Valvi Sujata R. Nutritional and Medicinal Attributes of Some Wild Edible Fruits of Kolhapur District. PhD Thesis, Shivaji University, Kolhapur, 2011; 314.

39. Jain SK. Wild Plant Foods of Tribals of Madhya Pradesh. Proc Nat Inst Sci. 1964; 30B: 56-88.

40. Oak Gayatri, Kurve Poonam, Kurve Siddhisha, Pejaver Madhuri. Ethno-botanical studies of edible plants used by tribal women of Thane District. . Journal of Medicinal Plants Studies. 3(2): 90-94.

41. Tiwari JK, Ballabha R, Tiwari P. Some Promising Wild edible Plants of Srinagar and its adjacent area in Alaknanda Valley of Garhwal Himalaya, India. Journal of American Science. 6(4): 167-174.

42. Kar IA, Bora D, Borthakur SK, Goswami NK, Sahar D. Wild Edible Plant Resources used by the Mizos of Mizoram, India. Kathmandu Uni J Sci Engg Tech. 9(1) 2013; 106-126.

43. Grivetti LE. Kalahari agro-pastoral hunter-gatherers: the Tswana example. Ecol Food Nutr. 1979; 7: 235-256.

44. Sullivan S. People, plants and practice in dry lands: socio-political and ecological dimensions of resource-use by Damara farmers in north-west Namibia. University College, London; 1998.

45. Arbonnier M. Arbres, arbustes et lianes des zones se'ches d'Afrique de l'Ouest. CIRAD/MNHN, Paris; 2002.

46. Cappers RTJ. Roman Food prints at Berenike. Costen Institute of Archaeology, Los Angeles. Monograph 55; 2006.

47. Chadha ML. Indigenous Vegetables of India with a Potential for improving livelihoods. Paper presented at: International Symposium on Underutilized Plants for Food Security, Nutrition, Income and Sustainable Development. International Society for Horticultural Science. ISHS Acta Horticulturae. 2006; p.806.

48. Kumar D, Kumar R, Thakur KS, Thakur Ashok, Thakur Prabal, Kumar S. Production Potential of Under Exploited Vegetable Crops. Vegetable Production under Changing Climate Scenario (Sept.1-Sept. 21). Department of Vegetable Science, YS Parmer Horticulture University, Nauni Solan; 2012.

49. Anywar G, Oryem-Origa H, Mugisha MK. Wild Plants Used as Nutraceuticals from Nebbi District, Uganda. Eur Uganda.European Journal of Medicinal Plants. 4(6): 641-660.

50. Swain MR, Anadraj M, Ray RC, Rani RP. 
Ahuja, S. C et al., Sch Acad J Biosci, July, 2020; 8(7): 187-209

Fermented fruits and vegetables of Asia: A Potential Source of Probiotics. Biotechnology Research International. 2014: 2014: 250424.

51. Motamedi H, Darabpour E, Gholipour M, Seyyed Nejad SM. In vitro assay for the anti-bucella activity of medical plants against tetracycline-resistant Brucella melitensis. J Zhejiang Univ Sci. 2010; 11(7): 506-511.

52. Ranjhan SK. Agro-Industrial by-products and non-Convential Feeds for Livestock Feeding. ICAR, New Delhi; 1990.

53. Chen Y, Wang Y, Zhou G, Li P, Zhang S. Key mediators modulating TAG synthesis and accumulation in woody oil plants. African $\mathbf{J}$ Biotech. 2008; 7(25): 4743-4749.

54. DARE/ICAR. Annual Report.2012-13; 56.

55. DARE/lCAR. Annual Report. 2014-15; 70.

56. Honeybee innovations http: //honeybee.org/honeybee_innovation.php?selectLa nguage $=$ en $\& \mathrm{q}=$ cordia $\&$ btnsearch $=$ Search

57. Rasulbahi Musebahi Vohra .Curing Diarrhoea in Animals.

58. Rasulbahi Musebahi Vohra. Remedy for Prolapse of Uterus in Animals.

59. Vejanandbhai Lakhmanbhai Ram. Foot and Mouth Disease in Animals.

60. Kalubhai Badhiabhai Pawar.Ease in Calving of Animals.

61. Harchandbhai D Patel. Aiding Cows and Buffaloes to Conceive.

62. Lakhmanbhai Bavchandbhai Patel. Treatment of Yoke Gall.

63. Santrambhai Kalidasbhai. Fracture of limb in Sheep and Goat.

64. Salave AP, Gopal Reddy PP. Some reports of Traditional Ethno- Veterinary Practices from Savagaon areas of Ashti Taluka in Beed District (MS) India. International J Applied Biology and Pharmaceutical Technology. 2012; 2(1): 115-119.

65. Rimbach L. Traditional Methods of Treating Cattle Diseases. Report for ASA (Studienaufenthalte in Africa, Asien und Latein-Amerika); 1977.

66. Swaleh A. Ethnoveterinary Medicine in Ormaland Kenya. Thesis M.Sc. Centre for Tropical Veterinary Medicine (CTVM). University of Edinburgh, UK. 1999; 35.

67. Ake-Assi YA. Contribution au recensement des espèces végétales utilisées traditionnellement sur le plan zootechnique et vétérinaire en Afrique de l'Ouest. Thèse de doctorat (Sc. Vétérinaires), Lyon, Université Claude Bernard, 1992; 220.

68. Kokwaro JO, Medicinal plants of East Africa. East African literature Bureau, Kampala, Nairobi, Dar -es Salam; 1976.

69. Orwa C, Mutua A, Kindt R, Jamnadass R, Anthony S. Agroforestree Database: a tree reference and selection guide .version 4.0 2009. (http: //www.worldagroforestry.org/sites/treedbs/treedata bases.asp)
70. Khalid H, Wail EA, Abdelgadir H, Opata T, Efferth T. Gems from traditional north-African medicine: medicinal and aromatic plants from Sudan. Nat Prod Bioprospect. 2012; 2, 92-103.

71. Kizaibek M, Kopp Brigette, Prinz Sonja et al. Antiproliferative activity of individual herbs of Abnormal Savda Munziq on HL-60 Cells. Sci Tech Review. 2009; 27: 508-515.

72. Kizaibek M, Popescu Ruxandra, Prinz Sonja. Towards Modernization of the Formulation of the Traditional Uighur Medicine herbal preparation Abnormal Savda Munziq. Evid-Based. Compl. Alt. $10 ; 2012$.

73. Kuppast I J, Nayak PV. Diuretic activity of Cordia dichotoma Forster f. Fruits. Ind J Pharm Educ Res. 2005; 39: 186-187.

74. Mishra A, Garg GP. Antidiabetic activity of fruit pulp of Cordia dichotoma in alloxan induced diabetic rats. Int J Pharm Sci Res. 2011; (9): 2314 2319.

75. Sharma PV. Classical Uses of medicinal plants. . Chaukhamba Vishvabharati, Varanasi, Uttar Pradesh. India; 1986.

76. Baidhynath. Ayurved Sar Sangrah $12^{\text {th }}$ Edition, Sri Baidya Nath Ayurved Bhawan, Patna; 1982.

77. Kumar PGM, Shiddamallayya N. Wild edible plants of Hassan District, Karnataka: A role in ayurvedic formulation. International Journal of Herbal Medicine. 2016; 4(1): 16-24.

78. Singh Archana, Dubey N K. An ethnobotanical study of medicinal plants in Sonebhadra District of Uttar, Pradesh, India with reference to their infection by foliar fungi Journal of Medicinal Plants Research. 2012; 6(14): 2727-2746.

79. 72. Sulieman AM, El-Newary Samah A. Hypolipidemic Effect of Cordia dichotoma Forst. Pulp in High-fat Diet-Fed Rats. World Journal of Dairy \& Food Sciences. 2014; 9 (2): 260-271.

80. Singh B, Mall TP. Cordia dichotoma Forst. F.: A traditional Ethnomedicine. Inter J Plant Res. 2008; 21(1): 59-60.

81. Ahmed I, Beg AZ. Antimicrobial and phytochemical studies on 45 Indian medicinal plants against multi drug resistant human pathogens. J Ethnopharmacol. 2001; 74: 113-123.

82. Pal DC, Jain SK. Tribal Medicine, Naya Prokash, Kolkata; 1998.

83. Yadav RK, Prakash A. Aromatic Medicinal Plant Resources in Uttar Pradesh, India. Medicinal \& Aromatic Plants. 2014; 3: 160.

84. Chopra RN, Nayer SL, Chopra IC. Glossary of Indian Medicinal Plants, $3^{\text {rd }}$ Edition. Council of Scientific and Industrial Research, New Delhi, India; 1992.

85. Manjula RR, Koteswara Rao J, Seetharami Reddi TVV. Ethnomedicinal plants used to cure jaundice in Khammam district of Andhra Pradesh, India. J Phytol. 2011; 3: 33-35. 
Ahuja, S. C et al., Sch Acad J Biosci, July, 2020; 8(7): 187-209

86. Zereen Arifa, Khan Z, Sardar AA. An Assessment and Documentation of Conventional Medico-Botanical Knowledge of Indigenous Communities Around Chichawatni Plantation Reserved Forest. The Pharmaceutical and Chemical Journal. 2015; 2(4): 27-35

87. Atta-ur-Rahman, Choudhary MI, Bullo S. Medicinal Plants of Sindh. Indigenous Knowledge and Scientific Fact Planning and Development Department Government of Sindh; 2013.

88. Roy GP, Chaturvedi. Ethno Medicinal Trees of Abujh -Marh ( Pesr Bastar Dist) MP. Folklore.1986; 5: 95-98.

89. Oudhia, P. Cordia myxa L. In: Schmelzer, G.H. \& Gurib-Fakim, A. (Editors). PROTA (Plant Resources of Tropical Africa / Ressources végétales de l'Afrique tropicale), Wageningen, Netherlands. 2007. Accessed 2 March 2020; https: //uses.plantnet-project.org/en/Cordia_myxa_(PRO TA)

90. Chaudhary Shalu. Medicinal plants of district Bijnor (U.P.) India with special reference to their folk medicinal uses. Journal of Experimental Sciences. 2011; 2(4): 19-23.

91. Patel NK, Patel IC, Seliya AR, Parmar N. Ethno medical Plants of North Gujarat-Part II. In Herbal Cures- Traditional Approach. Patil DA Editor, Aavishkar Publishers\& Distributors, Jaipur, India, 2008; 197-217.

92. Jain A, Katewa SS, Galav PK, Sharma P. Medicinal plant diversity of Sitamata wildlife Sanctuary, Rajasthan, India. Journal of Ethnopharmacology. 2005; 102: 143-157.

93. Rajashekar K, Thupurani MK, Marupati S, Prasad TS, Kanubaddi K. Cordia dichotoma crude extracts: potent source of natural antibacterial and antioxidant agents. Inter J Adv Res. 2014; 2: 65-73.

94. Compendium of Medicinal plants used in Malaysia. Herbal Medicine Research Centre, Institute for Medical Research, Kuala Lumpur; 2002.

95. Dinesh V, Bembrekar SK, Sharma PP. Traditional Knowledge of Medicinal Plants Used for the Treatment of Skin Diseases in Nizamabad District, Andhra Pradesh. Inter J Pharm Chem Sci. 2013; 2(3): 1488-1490.

96. Ashton MS. Gunatilleke Savitri, de Zoysa Neela, Dassanayake MD, Gunatilleke N, Wijesundera S. A Field Guide to the Common Trees and Shrubs of Sri Lanka. WHTT Publications (Pvt.) Limited. Colombo, Sri Lanka; 1997.

97. Patel AK and Pathak NL. Role of Cordia dichotoma on behavioral changes by using long-term hypoperfusion in rats. International Journal Pharmaceutical Research and Development. 2011; 3: 6-17.

98. Achaya D. 20 Herbs from Tribal Domain for Removing Acidity.http: //www.greenmedinfo.com/blog/20-herbs-tribal-do main-remedying-acidity
99. Singh D, Kumar K, Chandel RS. Biodiversity of wild fruits in Western Himalayas. Asian Agri-History. 2000; 4(3): 233-240.

100. Achal ji Maharaj. Sugham Chikitsa, Swami Achal Narayan, Jodhpur; 1961.

101. Anis M, Iqbal M. Medicinal Plantlore of Aligarh, India. Inter J Pharmacog. 1994; 32(1): 59-64.

102. Raja sahib AH, Isaq M. Documentation of folk knowledge on edible wild plants of Karnataka. Indian Journal Tradational Knowledge. 2004; 3(4): 419-429.

103. Husain S Z, Riffat N M, Mubashera Javaid, Sadia Bibi. Ethnobotanical Properties and Uses of Medicinal Plants of Morgah Biodiversity Park, Rawalpindi. Pak J Bot. 2008; 40(5): 1897-1911.

104. Bouby L, Bouchette A, Figueira Isabel. Sebesten fruits (Cordia myxa L.) in Gallia Narbonensis (Southern France): a trade item from the Eastern Mediterranean. Veget Hist Archaeobot. 2011; 20: 397-404.

105. Bodding PO Rev. Studies In Santal Medicine and Connected Folklore. The Asiatic Society, Calcutta, India; 2001.

106. Hooper D. Useful Plants and Drugs of Iran and Iraq. Field Museum of Natural Histo -Botanical Series. 1937; 9(3): 73-217.

107. Amiri MS, Joharchi MR. Ethnobotanical investigation of traditional medicinal plants commercialized in the markets of Mashhad, Iran. Avicenna Journal of Phytomedicine. 2013; 3(3): 254-271.

108. Malhotra SP, Dutta BK, Guta RK, Gaur YD. Medicinal plants of the Indian arid zone. $J$ d'agriculture tropicale et de botanique appliqué. 1996; 13(6-7): 247-288.

109. Banne S, Naik MK, Parida NK, Girigaon Y. Ethanomedicinal Studies of Some Trees in Jambooti village and its surrounding, Belagaum, Karnataka. International Journal of Biological \& Pharmaceutical Research. 2014; 5(9): 728-735.

110. Pandey AK, Rout SD. Ethnobotanical uses of plants of Similipal Biosphere Reserve (Orissa). International Journal of the society of Ethnobotanist. 2006; 18: 102-106.

111. 1Mariita RM, Ogol CKPO, Oguge NO, Okemo PO. Antitubercular and Phytochemical Investigation of Methanol Extracts of Medicinal Plants Used by the Samburu Community in Kenya. Tropical Journal of Pharmaceutical Research. 2010; 9 (4): 379-385.

112. Omwenga EO, Okemo PO, Mbugua PK, Ogol CKP. Ethnobotanical Survey and Antimicrobial Evaluation of Medicinal Plants used by the Samburu Community (Kenya) for treatment of Diarrhoea. Pharmacognosy Magazine. 2009; 4(18): 165-176.

113. Salave AP. Traditional Oral Healthcare Practices in Pathardi Areas of Ahmednagar District, Maharashtra, India. Bull Environ Pharmacol Life Sci. 2012; 1(7): 84-88. 
114. Glover PE, Stewart J, Gwynne MD. Maasai and Kipsigis notes on East African plants, Part III Medicinal uses of plants. . East African Agricultural and Forestry Journal. 1966; 32(2): 200 - 207.

115. Fratkin E. Traditional Medicine and concepts of healing among Samburu Pastoralists of Kenya. Journal of Ethnobiology. 1996; 16(1)-63-97.

116. Ichiwaka M. A Preliminary report on the Ethnobotany of the Suei Doroso in Northern Kenya. Pharmaceutical Sciences African Study Monographs, Suppl.7. 1987; 1-52.

117. http: //jambo.africa.kyoto-u.ac.jp/kiroku/asm_suppl/abst racts/pdf/ASM\%20\%20Sup.7/Mitsuo\%20ICHIKA WA.pdf

118. Muniafu MM, Kipkore KW, Maima AO, Kwena MO. Survey of Medicinal Plants used by Giriama of Basi, Kenya. Pharmological J of Kenya. 2014; 21(4): 9-18.

119. Bossard E. La médecine traditionnelle au centre et à l'ouest de l'Angola. Ministério da ciênciae da tecnologia. Instituto de investigaçâo cientifica tropical. Lisboa; 1996.

120. Nanyingi MO, Mbaria JM, Lanyasunya AL, Wagate CG, Koros KB, Kaburia HF, Munenge RW, Ogara WO. Ethnopharmacological survey of Samburu District, Kenya. Journal of Ethnobiology and Ethnomedicine. 2008; 4: 14.

121. Samuelsson G, Faraha MH, Per Claeson Hagos, Thulin M, Hedberg M, Warfa O. Inventory of plants used in traditional medicine in Somalia. I. Plants of the families Acanthaceae Chenopodiaceae. Journal of Ethnopharmacology.1991; 35: 25-63.

122. Hassan-Abdallah A, Merito A, Hassan S, Aboubaker D, Djama M, Asfaw Z, Kelbessa E. Medicinal plants and their uses by the people in the Region of Randa, Djibouti. Journal of Ethnopharmacology. 2013; 148: 701-713.

123. Burkill HM. The Useful plants of West Tropical Africa. $2^{\text {nd }}$ Edition, Volume 1, Families A-D. Royal Botanic Gardens, Kew. Richmond, United Kingdom; 1985.

124. Salave AP, Gopal Reddy PP, Diwakar PG. Some unreported Ethnobotanical uses from Karanji Ghat area of Pathardi Tahsil in Ahmedgarh District (MS) India. International J. Applied Biology and Pharmaceutical Technology. 2011; 2(4): 240-246.

125. Sen P. Traditional Plant Use in Family Welfare. In Herbal cures traditional Approach. Patil DA editior, Aavishkar Publishers, Distributors, Jaipur. India; 2008.1-41.

126. Malhi BS, Trivedi VP. Vegetable anti-fertility drugs of India. Quarterly Journal of Crude Drug Research. 1972; 12: 1922-1928.

127. Dee Smith Liana, Obel Elizabeth. Uses of Shrubs and Trees Identified by Chidren in Kenya. Project
Director, Trees Competition, Maziigira Institute, Nairobi; 1980.

128. Jagtap SD, Deokule SS, Bhosle SV. Some unique ethnomedicinal uses of plants used by the Korku tribe of Amravati district of Maharashtra. India. Journal of Ethnopharmacology. 2006; 107: 463-469.

129. Mali PR. Ethanobotanical Studies of Peth and Tribmbakeshwar District Nasik, Maharashtra, India. Trends Life Sciences. 2012; 1(4): 35-37.

130. Tayade SK, Patil DA. Ethnomedicinal wisdom of tribals of Nandurbar district (Maharashtra). Nat Prod Rad. 2006; 5(1): 64-69.

131. Shah Rajiv, Shah A R. Functional foods Newer opportunities for Indian food Industry to surge ahead. Industrial Researcher. 2006; 1-23.

132. 124. Marwat SK, Fazal-ur-Rehman, Usman Khalid, Khakwani AA, Ghulam Said et al. Medico-ethnobotanical studies of edible wild fruit plants species from the flora of north western Pakistan (D. I. Khan district). Journal of Medicinal Plants Research. 2011; 5(16): 3679-3686.

133. Shastri AM, India as Seen in the Brhatsamhita of Varahmihira. Motilal Banarasidass. Delhi. India; 1969.

134. Sadhale N. (translator) Surapala's Vrikshayurveda -The Science of Plant Life by Surapala. Agri-History Bulletin No.1 Asian Agri-History Foundation, Secunderabad, India; 1996.

135. Ahuja SC. Ahuja Uma, Sharma RD. Ayurvedic Characterization of Biopesticides. Asian Agri History. 2007; 11(2): 103-118.

136. 128. Ahuja SC, Ahuja Uma, Ahuja Siddharth. Nirgundi (Vitex negundo) - Nature's Gift to Mankind. Asian Agri-History. 2015; 19(1): 5-32.

137. Mittre V. Wild Plants in Indian Folk life- A historical prospective. In Contributions to Indian Ethnobotany. Jain SK editor, Scientific Publishers, Jodhpur, India, 1991; 39-59.

138. Kipkore W, Wanjohi B, Rono H, Kigen G. A Study of the Medicinal Plants used by the Marakwet Community in Kenya. Journal of Ethnobiology and Ethnomedicine. 2014; 10: 24

139. Stiles D, Kasam Aneesa. An Ethno-Botanical Study of Gabra Plant Use in Marsbit District, Kenya. J. East African Natural History Soc and National Museum. 1991; 81: 14-37.

140. Schlee G. The Social and the Belief System of the Rendille - Camel Nomads of Northern Kenya: English version (German Original: Berlin 1979); 2014.

141. Oniang'o R, Jallotey J, Malaba SJ. The (healthy, sustainable) Food Chain. Symposium 1, Part 3. 2004: 89-97. http: //iufost.org/wp-content/uploads/The_Food_Chain. pdf

142. Wasnoga VO. Nyariki DM, Ngugi RK. Assessing Socio- Ecological Change dynamics using Local knowledge in the Semi- Arid low lands of Baringo 
Ahuja, S. C et al., Sch Acad J Biosci, July, 2020; 8(7): 187-209

District, Kenya. Enviornment Res J. 2011; 5(1): 11-17.

143. Rathore Mala. Nutrient content of important fruit trees from arid zone of Rajasthan. Journal of Horticulture and Forestry. 2009; 1(7) L: 103-108.

144. Jamkhande PG, Barde SR, Shailesh L, Patwekar Priti, Tidke S. Plant profile, Phytochemistry and pharmacology of Cordia dichotoma (Indian cherry): A review. Asian Pacific Journal of Tropical Biomedicine. 2013; 3(12): 1009-1012.

145. Aberoumand A. Preliminary evaluation of some phytochemical and nutrients constituents of Iranian Cordia myxa fruits. Int J Agric Food Sci. 2011; 1(2): 30-33.

146. Aberoumand A, Deokule SS. Proximate and mineral co.mposition of the Sepestan (Cordia myxa R.) as a plant food. Journal of Medicinal Food Plants. 2009; 1(2): 92-96.

147. Aberoumand A, Deokule SS. Screening of some nutrients and anti-nutrients components in some plant foods of Iran and India. Journal of Agricultural Technology. 2010; 6(4): 777-781.

148. Pandey B, Deshpande B, Singh S, Chandrakar V. Estimation of elemental contents of Cordia myxa and its antimicrobial activity against various pathogenic micro-organisms. Ind J Sci Res. 2014; 4(1): 39-44.

149. Duhan A, Chauhan BM, Punia D. Nutritional Value of some Non-conventional Plant Foods of India. Plant Foods for Human Nutr. 1992; 42: 193-200.

150. Chauhan MG, Chavan SS. Pharmacognosy and Biological activity of Cordia rothii bark Roem. \& Schultz. Bark. Indian Journal of Traditional Knowledge. 2009; 8(4): 598-601.

151. Al-Snafi AE. The Pharmacological and therapeutic importance of Cordia myxa- A review. IOSR Journal of Pharmacy. 2016; 6 (6): 47-57.

152. Patel AK, Pathak N, Trivedi H, Gavania M, Patel M, Panchal N. Phytopharmacological properties of Cordia dichotoma as a potential medicinal tree: an overview. Int J. Inst Pharm Life Sci. 2011; 1(1): 40-51.

153. Ragasa CY, Jr. Ebajo V, Mariquit M, Reyes De Los, Mandia Emelina H, Tan Maria CS. Chemical Constituents of Cordia dichotoma G. Forst. Journal of Applied Pharmaceutical Science. 2015; 5(2): 016-021.

154. Thirupathi K, Kumar SS, Raju VS, Ravikumar B, Krishna DR. A review of medicinal plants of the genus Cordia: their chemistry and pharmacological uses. J Nat Rem. 2008; 8: 1-10.

155. Singh R, Lawania RD, Mishra A, Gupta R. Role of Cordia dichotoma seeds and leaves extract in degenerative disorders. International Journal of Pharmaceutical Sciences Review and Research. 2010; 2(1): 21-24.

156. Wang Y, Ohtani K, Kasai R, and Yamasaki K. Flavonol glycosides and Phenolics from leaves of Cordia dichotoma. Nat Med. 1996; 50: 367.
157. Chauhan JS, Srivastava SK, Sultan M. Hesperitin-7-rhamnoside from Cordia obliqua. Phytochemistry. 1978; 17: 334.

158. Jagdish S, Chauhan JS, Srivatava SK.1978. Lupa-20, 29-ene-3-o- $\beta$-D-maltoside from the roots of Cordia Obliqua. Phytochemistry. 17: 1005-6.

159. Miralles J, Noba K, Bassene E. Herba Hungarica 1989; 28(1-2): 7-12.

160. Wassel G, el-Menshaw B, Saud A, Meharuna G, el-Merzabani M. Screening of selected plant for Pyrrolizidine alkaloids and antitumor activity. Die Pharmazie. 1987; 42(10): 709

161. Afzal M, Obuekwe C, Shuaib N, Barakat H. Photosynthetic pigment profile of Cordia myxa L. and its potential in folklore medicinal application. J. Food Agric and Enviornm. 2004; 20: 114-120.

162. Bhattacharya P, Saha Achintya. Evaluation of reversible contraceptive potential of Cordia dichotoma leaves extract. Rev bras Farmacogn. 2013; 23(2). https: //doi.org/10.1590/S0102-695X2013005000020

163. US $6238674 \quad$ B1 https: //patentimages.storage.googleapis.com/b1/21/c8/0 486499aa9ef0f/US6238674.pdf

164. Karami MA, Moghimipour E, Saafi SF. Preparation and Evaluation of Cordia myxa Fruit Topical Cream. World Journal of Pharmaceutical Research. 2015; 4(7): 245-252.

165. Vidyasagar G, Jadhav AG, Narkhede SP, Narkhede SB. Isolation and Comparative Evaluation of Cordia dichotoma Forst. Mucilage as a Binding Agent with Standard Binder. J Chem Pharm Res. 2010; 2(4): 722-726.

166. Kassem A, el-Gendy A. Use of Cordia myxa mucilage to prevent capping in tablet manufacture. Bull Fac Pharm Cairo Univ. 1969; 8: 233-241

167. Moghimipour E, Aghel N, Adelpour A. Formation and characterization of oral mucoadhesive chlorhexidine tablets using Cordia myxa mucilage. Jundishapour J Nat Pharmacet Products. 2012; 7(14): 129-133.

168. Doharey V, Sharma Nisha. The permutation role of fenugreek seeds starch and Gunda glue as a binder in Paracetamol tablets. J Pharm Sci \& Res. 2010; 2(2): 64-68

169. Jain SK, Dam Nandita (nee Goon). Some ethno-botanical notes from north eastern India. Economic Botany. 1979; 33(1): 52-56.

170. Haq MA. Alam MJ, Hasnain AA. Novel Edible Coating to increase Shelf life of Chilgoza (Pinus geradiana). Food Science and Technology. 2013; 50(1): 306-311.

171. Jayaramudu J, Maity A, Sadiku ER, Guduri BR, Rajulu AV, Ramana CH. Structure and Properties of new natural cellulose fabrics from Cordia dichotoma. Carbohyd Polym. 2011; 86: 1623 1629.

172. Tahir Bashir Awad El, Jens Gebauer Jens. Non-timber Forest Products: Opportunities and 
Constraints for Poverty Reduction in the Nuba Mountains, South Kordofan, Sudan. Paper Presented at: Conference on International Agricultural Research for Development; 2004 October 5-7; Berlin: Deutscher Tropentag; 2004; $1-10$.

173. Khandelwal R, Sahu S, Arora SK, Mathur SP. A Green Approach for Corrosion Prevention. Int J Chemistry and Chem Engg. 2013; 3(3): 197-200.

174. Upadhyay R, Choudhary MS. Study of some Common Plants for Natural Dyes. Ind J Pharma Res Bio- Sci. 2012; 1(5): 309-316.

175. Organic and Vegetable Dyes- http: //www.stayorg.com/dyes/Dyes.

176. Badhwar RL, Dey AC, Edwards MV. The vegetable tanning material of India. Part 1: Survey. Indian Forester leaflet No. 1944; 722.

177. Ahirwar JR. The study on Coppicing capacity of Cordia myxa (Lasora). Int Res J Biol Sci. 2014; 3(2): 48-50.

178. Khandelwal SR, Shrivastava Y. Folk beliefs and practices related to plants conservation. Ind J Env Sci, Green Earth Foundation, Jaipur. 1989; 3(2): 165-170.

179. Weaver RE Jr., Anderson PJ. Botany Section. TRI-OLOGY. 2007; 46(3): 1-12.

180. Pareek A, Trivedi PC. Common Folk Proverbs in Relation to Environment and Plants in Rajasthan, India. J Indian bot Soc. 2014; 93 (1 \& 2): 100-104.

181. Pickled Cordia dichotoma- Challekayi Uppinakayi/Pickled Cordia Dichotoma http: //www.tasteofmysore.com/2009/06/challekayi-upp inakayipickled-cordia.html

182. Schippers A. Animal Descriptions in two qasidahs by Dhu 1_Rummah: Some Remarks. J Arab Lit. 1992; 23: 191-207.

183. Bhat MR, Nair BP. Hindu Astrology. Motilal Banarsidass Publishers. New Delhi; 1992.

184. Arnoldi MJ, Geary CM, Kris L. African Material Culture Indiana University Press, I ${ }^{\text {st }}$ Edition; 1996.

185. Tosco M. The Dhaasanac Language Rudiger Kaoppe Verlag. Koln; 2001.

186. Khazanov AM, Günther S (eds.). Who Owns the Stock? New York, Oxford, Berghahn; 2012.

187. Soga T. Sysytem and Reality: The Camel Trust System of the Gabra. African Study Monographs, 1997; 18(3, 4): 157-174.

188. Prakash OM. Food and Drinks in Ancient India. Munshi Ram Manohar Lal, Delhi; 1997.

189. Jha Ganganath. Manu: Manu-smrti: the laws of Manu; with the Bhasya of Medhathiti, translated; 1920. https: //www.wisdomlib.org/hinduism/book/manusmritiwith-the-commentary-of-medhatithi

190. Crooke W. Religion and Folklore of Northern India (Revised edition). S. Chand \& Co. Pvt. Ltd., New Delhi, India; 1896.

191. Lin CS, Tung C, Peng YC, Chow WK, Chang CS, $\mathrm{Hu}$ WH. Successful Treatment with a Combination of Endoscopic Injection and Irrigation with Coca Cola for Gastric Bezoar-induced Gastric Outlet Obstruction. J Chin Med Sci. 2008; 71(1): 48-52.

192. Gopalan C, Ramasastry BV, Balasubramanian SC. Nutritive value of Indian Food Stuffs. Indian Council of Medical Research, National of Nutrition, Hyderabad, India; 1984.

193. Agrahar-Murugkar D, Subbulakshmi G. Nutritive values of wild edible fruits, berries, nuts, roots and spices consumed by the Khasi Tribes of India. Ecology of Food and Nutrition. 2005; 44: 207-223.

194. Bhattacharya AK. Trees against dust pollution Cordia dichotoma -Pollution resistant tree in urban landscaping. Indian Forester. 1994; 120 (8): 658-669.

195. Chhonkar PK, Datta SP, Joshi HC, Pathak H. Impact of Industrial Effluents On Soil Health and Agriculture- Indian Experience Part II. Tannery and Textile Industrial Effluents. Journal of Science and Industry. 2000; 59: 446-454.

196. Al-Alti. Assyrian Plum (Cordia myxa L.) In Post Harvest Biology and Technology of Tropical and sub-topical fruits. Vol 2. Elhadi M.Yahia editor, Elsevier; 2011; 116-124.

197. Srivastava R. Underutilised Fruits: A Potential of Local food Resource. International Journal of Pharma \& Bio Sciences. 2013; 4(3B): 1301-1305.

198. Sinha MK. Threat Assessment of Medicinal Plants of Koria District in Chhattisgarh (India). IOSR Journal of Pharmacy and Biological Sciences (IOSR-JPBS). 2013; 5(2): 79-86.

199. Kuppast IJ, Nayak PV. Anthelmintic activity of fruits of Cordia dichotoma. Ind J Nat Prod. 2003; 19(3): 27-29.

200. Maisale AB, Attimarad SL, Haradigatti DS, Karigar A. Anthelmintic activity of fruit pulp of Cordia dichotoma. Int J Res Ayur Pharm. 2010; 1(2): 597-600.

201. Kuppast IJ, Nayak PV. Wound healing activity of Cordia dichotoma Forst. F. fruits. Nat Prod Rad. 2006; 5: 99-102.

202. Sharker S Md, Khadiza P, Shahid IZ. Analgesic, antibacterial and cytotoxic activity of Cordia dichotoma. Pharmacology online. 2009; 2: 195 202.

203. Shahapurkar AA, Jayanthi. Drug neomycin release from Cordia dichotoma transdermal film and anti-inflammatory activity. Int Res J Pharm. 2011; 2(9): 107-109.

204. Shah D, Prasad N, and Limbani B. Gasroprotective and antiulcer effect of Cordia dichotoma. Int Res J Pharm. 2011; 2(9): 70-72.

205. Abou-Shaaban, RRA, Al-Angari AA, El-Tahir KEH, Al-Khamis KI, Mirgani OM. Comparative hypotensive and respiratory stimulation effects of ripe and unripe fruit mucilage of Cordia myxa and Cordia obliqua in guinea pigs and rabbits, Phytotheraphy Res. 1989; 3(4): 117-164. 
Ahuja, S. C et al., Sch Acad J Biosci, July, 2020; 8(7): 187-209

206. Mishra A, Garg GP. Antidiabetic activity of fruit pulp of Cordia dichotoma in alloxan induced diabetic rats. Int J Pharm Sci Res. 2011; 2(9): 2314-2319.

207. Panghal M, Kaushal V, Yadav Jaya P. In vitro antimicrobial activity of ten medicinal plants against clinical isolates of oral cancer cases. Ann Clin Microbiol Antimicrobials. 2011; 10: 21-32.

208. Dhar ML, Dhawan BN, Prsad CR, Rastogi RP, Singh KK, Tandon JS. Screening of Indian plants for biological activity: Part V. Ind J Exp Biol. 1974; 12: $512-516$

209. Choudhary DN, Singh JN, Verma SK, Singh BP. Antifertility effects of leaf extracts of some plants in male rats. Ind J Exp Biol. 1990; 28: 714-716.

210. Pal M, Mishra T, Kumar R, Tiwari SK. Antitermite activity of Cordia dichotoma. Int J Sci Inno Res. 2013; 1(2): 67-71.

211. Jain Jyoti G, Bhore PG, Parmar JS, Hussain SA. Antidepressant activity of Cordia dichotoma leaf extracts in animal behavior models: a research. Int J Drug Form and Res. 2010; 1(1): 294-310.

212. Ganjare AB, Nirmal SA, Patil AN. Use of apigenin from Cordia dichotoma in the treatment of colitis. Fitoterapia. 2011; 82: 1052-1056.

213. Nariya PB, Bhalodia NR, Shukla VJ, Acharya R. Antimicrobial and antifungal activity of Cordia dichotoma (Forester F.) bark extracts. Ayusdhara. 2015; 32: 585-589.

214. Singh S, Rahesa M, Sharma S. Analgesic activity on different extract of Cordia dichotoma bark. Ind $\mathbf{J}$ Nat Prod. 2008; 24(1): 21.

215. Katolkar PP, Wanjari BE, Nimbekar TP, Duragkar NJ. Antiimplantation activity of the methanolic extract of Cordia dichotoma Lam. Bark in rats. Int $\mathrm{J}$ Biomed Adv Res. 2012; 3(3): 202-204.

216. Nariya PB, Bhalodia NR, Shukla VJ, Acharya R, Nariya MB. In vitro evaluation of antioxidant activity of Cordia dichotoma Forst f. Bark. Int J Ayur Res. 2013; 34(1): 124-128.

217. Yadav R, Chaubey A, Sharma A, Asthana A, Prashanti CH. Evaluation of Wound Healing Potential of Seeds and Leaves of Cordia Obliqua Wild. Int J Pharmacy Pharma Res. 2015: 2(3): 109-113.

218. Mahasweta R, Kumar B, Kumar N, Patel A, Kumar B. Antioxidant activity of taxifolin obtained from methanolic extracts of $C$. dichotoma Linn. Seeds. Int J Pharm Sci Res. 2014; 5(7): 2896-2901.

219. Yadav R, Yadav SK. Evaluation of antimicrobial activity of seeds and leaves of Cordia obliqua Willd against some oral pathogens. Indo-Am J Pharm Res. 2013; 3: 6035-43.

220. Afzala M, Obuekwe C. Khan AR, Barakat H. Antioxidant activity of Cordia myxa L. and its hepatoprotective. EJEAPChe. 2007; 6(6): 2109-2118.

221. 213. Al-Awadi FM, Srikumar TS, Anim JT, Khan I. Antiinflammatory effects of Cordia myxa fruit on experimentally induced colitis in rats. Nutrition. 2001; 17(5): 391-396.

222. Inas. Abdallah ZA. Khattab AH, Heeba Gehan H. Gastro-protective Effect of Cordia myxa L. Fruit Extract against Indomethacin-Induced Gastric Ulceration in Rats. Life Sci J. 2011; 8(3): 433-445.

223. Ashour OM, Abdel-Naim AB, Abdallah HM. Nagyd AA, Mohamadin AM, Essam A. Abdel-Sattarg. Evaluation of the Potential Cardio protective Activity of Some Saudi Plants against Doxorubicin Toxicity. 2012; Z. Naturforsch. 67c, 297-307.

224. Ranjbar M, Varzi HN, Sabbagh A, Bolooki A, Sazman A. Study on analgesic and antiinflammatory properties of Cordia myxa fruit hydroalkaloid extract. Pak J Biol Sci. 2013; 16(24): 2066-2069.

225. Ali Waheeda R, Al-Asady Zainab T, Ibrahim A, Abdul J. Immunomodulatory of Cordia myxa (L.) Aqueous Extract Fruit in Immunized Mice with Hydatid Cyst Fluid. J Nat Sci Res. 2015; 5(10): 75-82.

226. Saki J, Khademvatan S, Pazyar N, Eskandari A, Tamoradi A and Nazari P. In Vitro Activity of Cordia myxa Mucilage Extract Against Leishmania major and L. infantum Promastigotes. Jundishapur J Microbiol. 2015. 8(3): e19640.

227. Rapisarda A, Ficarra R, Tommasin S, Caldbro M, Hungsa S. Cordia francisci, C. martinicensis, $C$. myxa, C. serratifolia and Culmfolia leaves as new source of routine; Analgesic and anti-inflammatory activity. Planta Medica.1992; 42: 643.

228. Ficarra R, Ficarra P, Tommasini S, Calabro ML, Ragusa S, Barbera R, Rapisarda A. Leaf extracts of some Cordia species: analgesic and anti-inflammatory activities as well as their chromatographic analysis. Farmaco. 1995; 50: 245-256.

229. Wassel G, El-Menshaw B, Saud A, Meharuna G, El-Merzabani M. Screening of selected plant for Pyrrolizidine alkaloids and antitumor activity, Pharmazine. 1987; 42: 709.

230. Alami R, Macksad A, El Gindy. Medicinal plants in Kuwait, Al-Assriya Press, Kuwait; 1974.

231. Abdulhay Suhail Hind. The Effect of Alkaloid Extracted from Cordia myxa leaves on the Survival of Mustard Aphid Lipaphis erysimi (Kalt.). J Chem Biol Physic Sci. 2015; 6(1) 84-90.

232. Arora Kanika, Deswal Geeta, Dhingra A, Kriplani Priyanka, Kaur Gaganpreet. Anxiolytic activity of leaves extract of Cordia myxa L. in mice as an exaplary models of activity. World J Pharama Res. 2015; 4(10): 1377-1381.

233. Tiwari R.D, Srivastava KC, Shukla S, Bajpai RK. Chemical examination of the fixed oil from the seeds of Cordia myxa. Planta Med. 1967; 15(3): 240-244.

234. Al-Musayeib N, Shagufta P, Itrat F, Muhammad N, Ajaz H. Antioxidant, Anti-Glycation and 
Ahuja, S. C et al., Sch Acad J Biosci, July, 2020; 8(7): 187-209

Anti-Inflammatory Activities of Phenolic Constituents from Cordia sinensis. Molecules. 2011; 16: 10214-10226.

235. Firdous S. Khan, Zikr-Ur-Rehman K, Ali S, Soomro Z, Ahmad S, Rasheed VU, Mesaik MAM, Faizi S. Isolation of Phytochemicals from Cordia rothii (Boraginaceae) and Evaluation of their Immunomodulatory Properties. Rec Nat Prod. 2014; 8: 51-55.

236. Eltayeib AA, Ishag W. Phytochemical screening Antimicrobial, Antioxidant and cytotoxicity Activities of bark's crude extracts of Cordia sinensis. Advanc. Med Plant Res. 2015; 3(2): 39-45.

237. Zala AH, Pandya SS, Rabari HA. Wound healing activity of leaf extracts of Cordia rothii Roem \& Schult. Int J Pharm Life Sci (IJPLS), 2012; 3(10) 2048-2054.

238. El-Kamali HH, Ehsan EL-Karim MA. Evaluation of Antibacterial Activity of Some Medicinal Plants Used in Sudanese Traditional medicine for Treatment of Wound Infections. Acad J Plant Sci. 2009; 2(4): 246-251. 